\title{
WHICH REFORMS WORK AND UNDER WHAT INSTITUTIONAL ENVIRONMENT? EVIDENCE FROM A NEW DATA SET ON STRUCTURAL REFORMS
}

\author{
Alessandro Prati, Massimiliano Gaetano Onorato, and Chris Papageorgiou*
}

\begin{abstract}
Are structural reforms growth enhancing? Is the effectiveness of reforms constrained by a country's distance from the technology frontier or by its institutional environment? This paper takes a new and comprehensive look at these questions by employing a novel data set that includes several kinds of real (trade, agriculture, and networks) and financial (domestic finance, banking, securities, and capital account) reforms for an extensive list of developed and developing countries, going back to the early 1970s. First-pass evidence based on growth breaks analysis and on panel growth regressions suggests that on average, both real and financial sector reforms are positively associated with higher growth. However, on several occasions, botched reforms resulted in growth disasters. More important, the positive reform-growth relationship is shown to be highly heterogeneous and to be influenced by a country's constraints on the authority of the executive power and by its distance from the technology frontier. Finally, there is some evidence that crises, defined as severe growth downturns, are associated with subsequent reform upticks.
\end{abstract}

\section{Introduction}

$\mathrm{O}$ VER the past few decades, many countries have experienced remarkable progress in their economic performance. This coincided with an unprecedented wave of structural reforms, including trade and financial liberalization. Although there are many possible driving forces underlying this phenomenon the apparent; comovement between growth and a broad range of structural reforms deserves renewed attention. ${ }^{1}$

Do reforms promote growth? Which reforms really work? Do institutions supersede policies to explain economic performance? Or does the institutional environment play a role in how effective reforms are? These questions have been fiercely debated among academics and policymakers for a long time,

Received for publication May 24, 2010. Revision accepted for publication February 28, 2012.

* Prati: International Monetary Fund; Onorato: IMT Lucca; Papageorgiou: International Monetary Fund.

Corresponding author: Chris Papageorgiou.

In memory of our beloved Alessandro. We thank the editor Philippe Aghion, two anonymous referees, Daron Acemoglu, Andy Berg, CarlJohan Dalgaard, Alan Drazen, Simon Johnson, Ayhan Kose, Anne Krueger, Tommaso Nannicini, Jonathan Ostry, Dennis Quinn, Raghu Rajan, James Rauch, Richard Rogerson, Martin Schindler, Antonio Spilimbergo, Guido Tabellini, and seminar participants at the Southern Economic Association, Washington, DC, 2008, the AEA Meetings, San Francisco 2009, the INFINITI Conference on International Finance, Dublin 2009, the Workshop on the Political Economy of Reforms, Mannheim 2011, the IMF, and the University of Cyprus for valuable comments and suggestions. Manzoor Gill, Freddy Rojas Cama, Patricio Valenzuela, and Jair Rodriguez provided outstanding research assistance. We are grateful to the Research Department of the IMF for financial support. The views expressed in this study are the sole responsibility of the authors and should not be attributed to the International Monetary Fund, its executive board, or its management.

A supplemental appendix is available online at http://www.mit pressjournals.org/doi/suppl/10.1162/REST_a_00307.

${ }^{1} \mathrm{~A}$ reasonable concern is that the observed recent growth in resource-rich developing countries is primarily due to hikes in oil and other commodities' prices. However, it is still remarkable that growth has been so spectacular in most regions and countries of the world, including non-resource-rich countries. with not much progress in arriving at a conclusive answer. ${ }^{2}$ Testimony to how contentious and divisive discussions have been about the success and failure of certain reforms or packages of reforms is a voluminous literature that emerged by advocates and critiques of the Washington consensus, a list of policies originally proposed by John Williamson in $1990 .{ }^{3}$

Economic theory suggests that structural reforms should remove obstacles to an efficient allocation of resources, thereby increasing average income levels. At the same time, a perennial challenge for policymakers is finding ways to improve economic performance. This is difficult and complex task, but there is general agreement that structural reformssuch as reducing rigidities in product and factor markets, liberalizing capital flows, and freeing international tradeare an important part of an overall strategy for raising incomes and sustaining economic growth. Despite the importance of the issue, the analysis of the relevance of such policies in terms of economic performance has been limited by the lack of consistent historical data on reforms in many non-OECD economies.

While much is still to be learned about the connection between structural reforms and economic performance, several insights emerge from existing research. First, a wide body of empirical evidence documents that trade liberalization raises the level of real income in an economy as a result of improvements in efficiency. ${ }^{4}$ Furthermore, there seems to be a presumption that trade liberalization also raises an economy's long-run growth rate. Sachs and Warner (1995), for instance, construct a composite index of openness to international trade

${ }^{2}$ Easterly (2005), for instance, studies the association between a large set of economic policies and economic growth. Although baseline estimates suggest that better policies lead to a substantial increase in per capita income growth, once "extreme" cases of bad policies are removed from the sample policy, variables no longer display any relevant association with growth. Rodrik (2005) discusses how policies aimed at promoting economic growth can be highly context specific. Recent literature investigates whether institutions are more important than policies to explain countrywide differences in economic performance. The evidence that Easterly and Levine (2003) provide suggests that macroeconomic policies do not play a big role in explaining current levels of economic development once the effect of institutions is taken into account. They argue that bad policies might be "symptoms" of a deeper institutional weakness. Acemoglu et al. (2008) reach a similar conclusion.

${ }^{3}$ Williamson (2000) coined the phrase in 1990 "to refer to the lowest common denominator of policy advice being addressed by the Washingtonbased institutions to Latin American countries as of 1989."

${ }^{4}$ Frankel and Romer (1999) use country geographical characteristics as instruments for trade shares. Their results suggest that a rise of $1 \%$ point in the ratio of trade to GDP increases per capita income by $0.5 \%$. Anderson, Martin, and van Mensbrugghe (2006) estimate that the removal of all trade barriers would raise real income of the world by about US $\$ 287$ billion in 2015. However, Tokarick (2008) points out that all countries may not benefit, as some may face adverse movements in their terms of trade as a result of trade liberalization. 
and find that in the period from 1970 to 1989 open economies experienced an average growth 2.45 percentage points higher than closed ones. ${ }^{5}$ Dollar and Kraay (2004) use decade-overdecade variations in volume of trade as a proxy for change in trade policy. Openness to international trade appears to sustain higher income growth rates. Nevertheless, empirical research has not established a conclusive relationship between trade liberalization and economic performance (see Berg \& Krueger, 2003, for a survey). ${ }^{6}$

A large body of literature suggests that a well-developed financial sector promotes economic growth (Levine, 1997, 2005). However, relatively few studies try to assess the impact of financial sector reforms on economic growth. Bekaert, Harvey, and Lundblad's (2005) main measure of financial liberalization is a dummy variable equal to 1 for the years when foreign investors can own equities of a particular market. Equity market liberalization increases annual real per capita GDP growth by almost 1\%. Quinn and Toyoda (2008) provide detailed de jure measures of capital account and financial current account openness and document that capital account liberalization is positively associated with growth. Finally, recent empirical work provides evidence that structural reforms improve economic performance in advanced economies. Nicoletti and Scarpetta (2003) use an original data set on product market regulation in eighteen OECD countries and show that product market reforms raise productivity growth. Evidence on the impact of these kinds of structural reforms in emerging and developing economies does not exist.

Motivated by this literature, we take a broad look at the association between a wide range of structural reforms and economic growth. Specifically, we employ a newly constructed data set that includes information about several kinds of structural reforms in both the real and financial sectors of the economy for both industrialized and developing countries over roughly the past thirty years. Indices of structural reforms in the real sector of the economy measure, respectively, the extent of openness to international trade, the reduction of public intervention in the agricultural market, and the degree of liberalization in the telecommunication and electricity markets. Indicators of structural reforms in the financial sector encompass the overall domestic financial sector and two more specific subsectors: the banking and securities markets, respectively. A final set of indicators of

\footnotetext{
${ }^{5}$ Sachs and Warner (1995) define a country open to international trade if none of the following conditions holds: (a) nontariff barriers covering $40 \%$ or more of trade, (b) average tariff rates of $40 \%$ or more, (c) a black market exchange rate depreciated by $20 \%$ or more relative to the official exchange rate, (d) a socialist economic system, and (e) a state monopoly on major exports. Rodriguez and Rodrik (2000) discuss in depth whether the Sachs and Warner index provides an appropriate measure of openness to international trade.

${ }^{6}$ Rodrik, Subramanian, and Trebbi (2004), following Frankel and Romer (1999), instrument actual trade-to-GDP shares with those estimated on the basis of gravity equations for bilateral trade flows. Settlers' mortality rates from Acemoglu, Johnson, and Robinson (2001) are used as an instrument for the quality of institutions. Their results suggest that institutions are the main determinants of current differences in economic development.
}

financial sector reforms captures the degree of the external capital account openness. The richness of our data, in terms of both the sectors of the economy they refer to and of their time and country coverage, is essential to empirically investigating different hypotheses about the relationship between reforms and growth that have been suggested by recent literature.

We rely on two approaches. First, we investigate the relationship between reforms and growth breaks. The hypothesis that reforms cause growth accelerations is based on the observation that the output path in the advanced countries tends to be fairly steady, while it is often characterized by "mountains, cliffs, and plains" in developing economies (Pritchett, 2000). Growth breaks are broadly defined as extended periods of markedly high or slow growth. Hausmann, Pritchett, and Rodrik (2005), Berg, Ostry, and Zettelmeyer (2012), and Jones and Olken (2008) use this approach to understand the differential growth experiences of rich and poor countries. A related question is whether economic crises initiate the processes of structural reforms. An extensive literature tries to test this hypothesis (see, for instance, Drazen and Easterly, 2001). One of our aims is to look at these issues by using the growth breaks approach.

Second, we present estimates about the association between the reform indicators and economic growth based on panel data analysis that controls for country and time fixed effects. We then move to an empirical assessment of the extent to which country-wide key variables like the distance to the technological frontier ${ }^{7}$ and the broad institutional environment, 8 reinforce the impact of structural reforms on economic performance. Finally, we provide an extensive analysis of the robustness of our main results to the inclusion of additional covariates, different time periods and income groups, and the use of lower-frequency data.

Our main findings are as follows: growth breaks and growth regression analyses provide evidence that both real

\footnotetext{
${ }^{7}$ A line of research in economics, building on the Schumpeterian growth paradigm (see, for instance, Aghion \& Howitt, 2006), emphasizes that the design of policies aimed at fostering economic growth is context specific and depends on a country's distance to the world technological frontier. According to this theoretical framework, a proper empirical assessment of the relevance of different pro-growth policies requires taking into account the possibility for nonlinear effects arising from a country's distance to the technological frontier.

8 Acemoglu et al. (2008) also point to the possibility that policy reforms may have nonlinear effects, which, in their view, are determined by the degree of the institutional constraints imposed on politicians' behavior. More specifically, their theoretical analysis predicts that reforms have a less relevant impact on economic outcomes in countries with high or low levels of constraints on executive power. In the first case, politicians, who are highly accountable and constrained in their power, are less likely to implement, in the first instance, de facto distortionary policies. Therefore, de jure reforms should have a less dramatic impact on economic outcomes. On the other hand, in contexts characterized by weak mechanisms of political accountability, de jure reforms can be easily (de facto) undermined and, consequently, be of more limited impact. In countries with intermediate levels of constraints on politicians, the institutions are not sound enough to make bad economic policies rare, but at the same time they are not so weak that de jure reforms can be easily disregarded. Under such circumstances, the authors expect that policy reforms should be more effective at achieving the goals they are designed for.
} 
and financial sector reforms are on average positively associated with growth. Among real sector reforms, openness to international trade and a lesser public intervention in the agricultural market have a significant positive association with growth, while reforms in the network industries (electricity and telecommunications) are not significant. Among financial sector reforms, both domestic financial reforms and capital account liberalization are significantly correlated with higher growth. These conditional correlations exhibit substantial variation across reforms influenced by the distance to the technological frontier and the level of a country's constraint on executive power and are heterogeneous across different time periods and country income groups. It is also shown that on several occasions, botched reforms resulted in growth disasters. Finally, there is some evidence that severe growth downturns are associated with subsequent reform upticks. Numerous robustness checks show that the baseline results hold up quite well to alternative specifications, estimation method, and data frequency.

The remainder of the paper is organized as follows. Section II describes the recently constructed structural reform indices. Section III reports and discusses our main findings concerning growth breaks and baseline regression analysis, as well as the extent to which the distance to the technological frontier and the quality of the institutions influence the association between reforms and growth. Section IV presents an extensive robustness analysis of the baseline results, and Section V concludes.

\section{A First Look at the Data}

This section provides an introduction to the indices of structural reforms we consider in the analysis and describes their time patterns at the aggregate and regional level and by grouping countries according to institutional quality.

The key advantage of our structural reform data over those used in previous work is that they have a long time series dimension (around thirty years) and comprise a large number of countries (over ninety countries), including advanced and developing economies. ${ }^{9}$ The indicators of reforms in the real sector of the economy regard openness to international trade and product market liberalization. Openness to international trade is measured along two dimensions: average tariff rates and restrictions on current account transactions (including payments and receipts on exports and imports of goods and services), respectively. Two different indices capture the degree of structural reforms undertaken in the product markets. The first refers to the agricultural sector. It measures the extent of public intervention in the market of each country's

\footnotetext{
${ }^{9}$ For some reforms (trade, agriculture, networks, and current account), the data go back to 1960 and cover more than 100 countries. The complete list of the countries included in the sample and detailed information about the methodology used to construct the different indicators (along with their time and country coverage) are reported in appendixes 1 and 2, respectively in the online supplement.
}

main agricultural export commodity. It includes the presence of export marketing boards and the incidence of administered prices. The second measures the degree of liberalization in the telecommunications and electricity markets, including the extent of competition in the provision of these services and the existence of an independent regulator.

Among the indicators of financial sector reforms, the index of domestic financial liberalization is derived from the database constructed by Abiad, Detragiache, and Tressel (2008). It is an average of six subindices. Five of them refer to the banking system and cover (a) credit controls, such as subsidized lending and directed credit; (b) interest rate controls, such as floors or ceilings; (c) competition restrictions, such as entry barriers and limits on branches; (d) the degree of state ownership; and (e) the quality of banking supervision and regulation. The sixth dimension relates to the securities markets and captures the degree of legal restrictions on the development of domestic bonds and equity markets, as well as the existence of independent regulators. When investigating the association between reforms in the domestic financial sector and economic growth, we use both the overall index of domestic financial liberalization and the two different subindices that relate to the banking and securities sectors.

Another indicator of financial sector reforms is the index of external capital account liberalization, which measures a broad set of restrictions on financial transactions for residents and nonresidents, as well as the use of multiple exchange rates. In the empirical analysis, we use both this aggregate measure and the two separate indicators of external capital account openness for resident and nonresident. The last two subindices measure, respectively, the intensity of legal restrictions on residents' versus nonresidents' ability to move capital in and out the country.

All indicators are rescaled to range between 0 and 1, with higher values corresponding to a greater degree of liberalization. Differences in values of each index across countries and over time provide useful information on the variation in the absolute degree of economic liberalization within each sector. Instead, differences in the value of the indices across sectors do not provide a precise quantitative measure of whether one sector is more liberalized than another because of the different methodology used to construct each index. For instance, a positive difference between the trade index and the financial index does not necessarily mean that trade is more liberalized than the financial sector.

As shown in figure 1, all six indices we consider (international trade, current account, networks, agriculture, capital account, and domestic finance) trend upward over time toward a high degree of liberalization. The liberalization of international trade, capital movements, and the domestic financial sector has been fairly steady and gradual over the past three decades, whereas product market reforms (agriculture, electricity, and telecommunications) started only around 1990. There have been no global setbacks in the reforming 
Figure 1.-STRUCTURAL Reforms Indices, All Countries

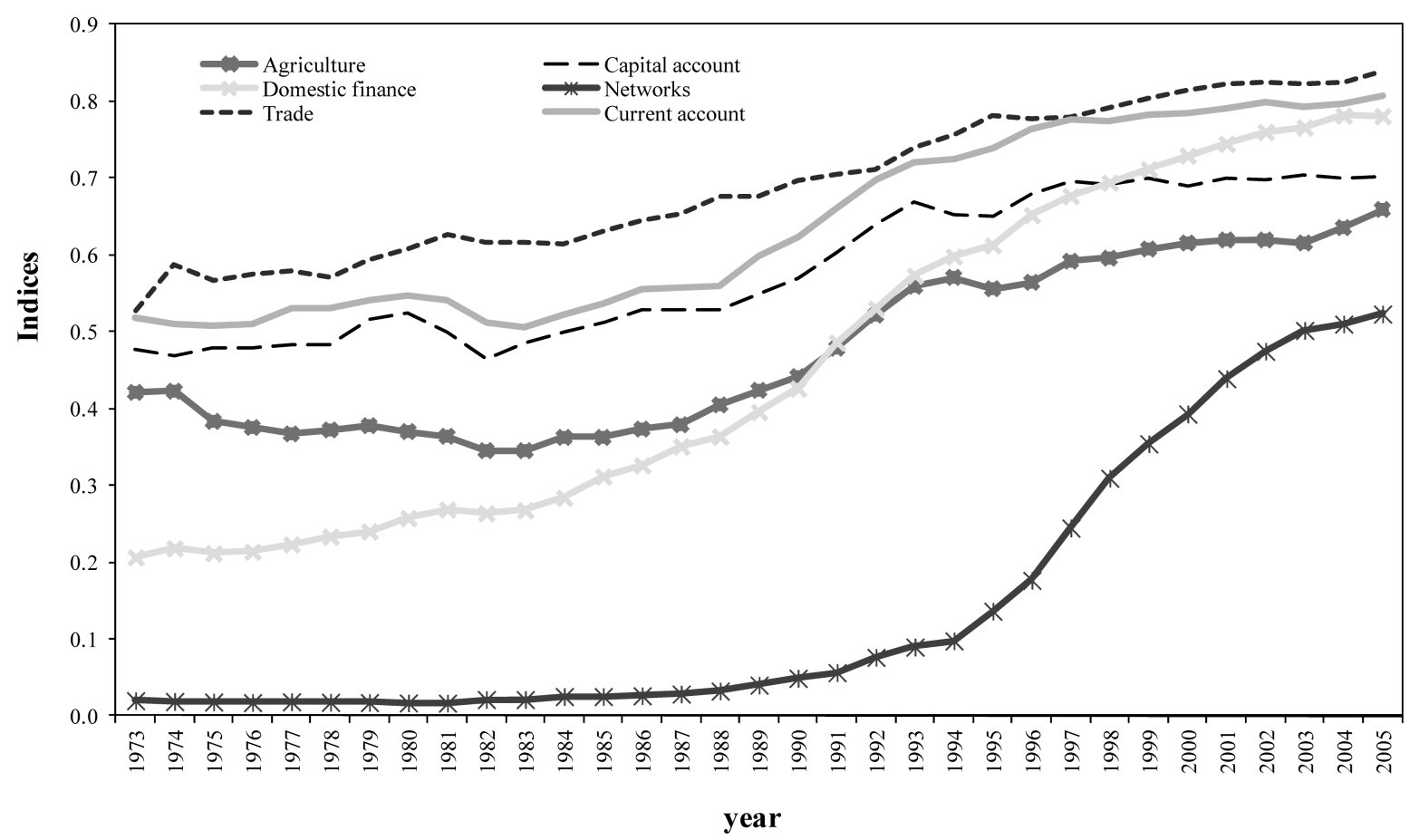

Source: IMF estimates.

Higher values of the indices denote a larger degree of structural reforms. Each index is rescaled to range between 0 and 1 . Their plotted values correspond to the mean of each index across countries in a given year "Agriculture" captures public intervention in the market for each country's main agricultural export commodity. "Domestic finance" takes into account restrictions on the interest rate determination and the banking sector's competition, credit controls, and quality of supervision in the banking sector, as well as the degree of liberalization of securities markets. "Trade" denotes average tariff rates. "Capital account" is an indicator of restrictions on financial credits and personal capital transactions for residents and financial credits for nonresidents. "Networks" captures the degree of competition and liberalization and the quality of regulation in the electricity and telecommunications markets. "Current account" denotes current account restrictions on the proceeds from international trade in goods and services. See appendix 2 for more details.

process, in any sector. Structural reform indicators display significant differences across regions (figure 2), pointing to a process of catching up with the levels of sectorial reforms that characterize the industrial economies.

Panels in Figure 3 depict the evolution over time of our indices for countries grouped according to a specific measure of quality of political institutions: the degree of constraints on the executive power. This variable, taken from the Polity IV project, ranges from 1, denoting no regular limitations on the executive's power, to 7, denoting countries where political bodies such as legislatures have equal or even larger authority than the executive (see Marshall, Gurr, \& Jaggers, 2010). Following Acemoglu et al. (2008), we classify the countries into three categories of high, medium, and low constraints on the executive. ${ }^{10}$

All measures of reforms show a broad upward trend over time in the three groups of countries we consider; the only less clear-cut cases are current and capital account openness in countries with low constraints on the executive. Notwithstanding substantial country-specific heterogeneity, economies with better political institutions are generally characterized by higher values of the reform indicators.

\footnotetext{
${ }^{10}$ For each country we compute the sample mean of the variable constraints on the executive. Countries above, within, and below 1 standard deviation from the sample mean are assigned, respectively, to the categories of high, middle, and low constraints on the executive.
}

\section{Estimation and Results}

The empirical baseline analysis is organized around four related parts. Section IIIA investigates the correlation between the reform indices and growth spells, motivated by the recent literature on growth accelerations (see Hausmann et al., 2005). Section IIIB investigates the association between reforms and trend growth based on OLS regressions that control for country and time fixed effects. Sections IIIC and IIID examine to what extent the reforms-growth relationship is influenced by a country's distance from the technological frontier and by the institutional environment, respectively.

\section{A. Reforms and Growth Spells}

In this section we present evidence from graphical analysis about the association between different types of real and financial structural reforms and growth spells. Growth spells, broadly defined as extended periods of very rapid or markedly slow growth, are a striking feature of the development process in many countries. Hausmann et al. (2005), Berg et al. (2012), and Jones and Olken (2008) rely on this new approach to the data analysis to understand the different growth experiences of rich and poor countries. ${ }^{11}$ This section

11 Two early precursors of the current work on growth spells are BenDavid and Papell (1998) and Pritchett (2000), both of which employ novel econometric methods to identify shifts in growth performance. 
Figure 2.-STRUCTURAL REFORM INDICES By REGION
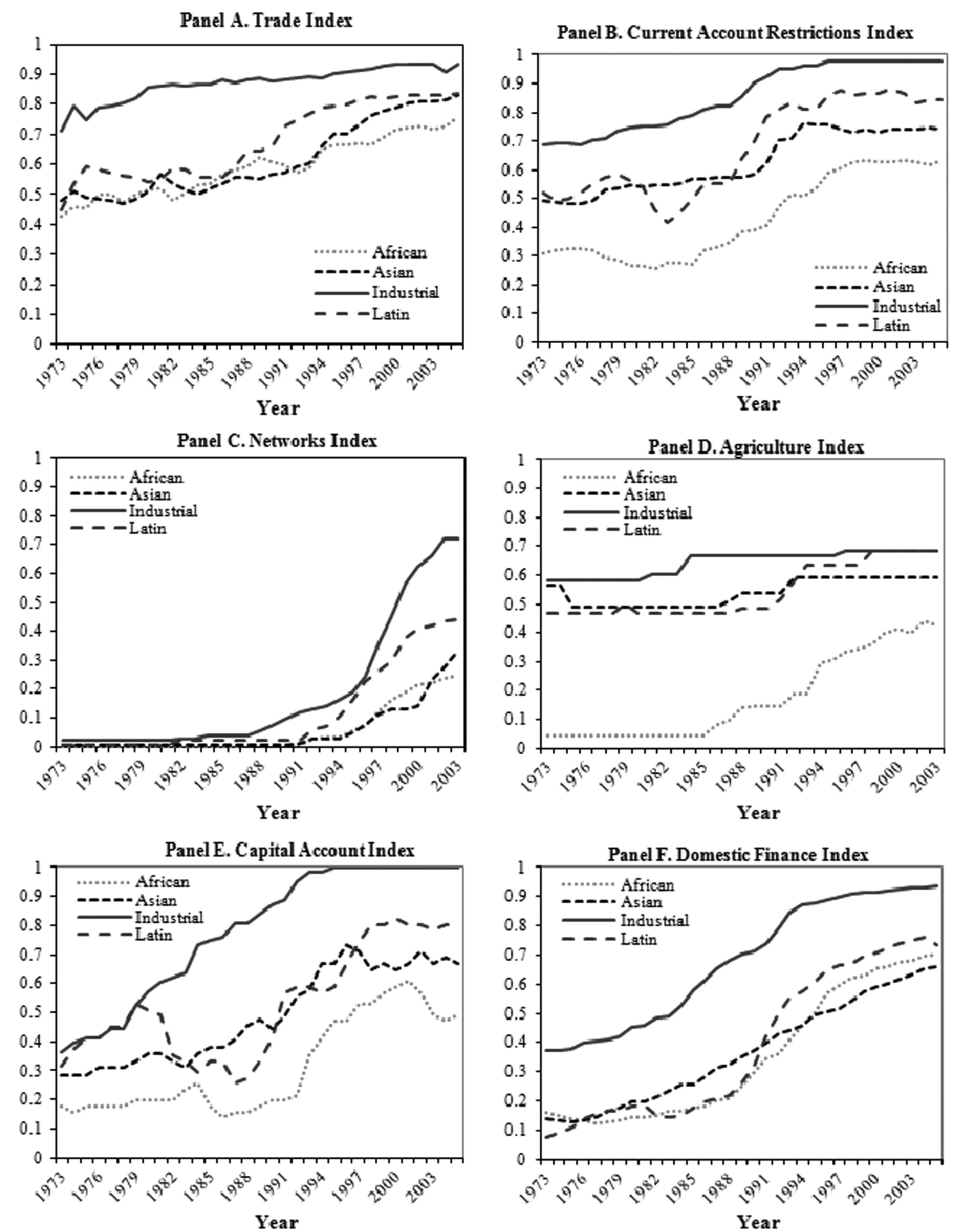

Source: IMF estimates.

Higher values of the indices denote a larger degree of structural reforms. Each index is rescaled to range between 0 and 1 . Their plotted values correspond to the mean of each index across countries in a given year. "Trade" denotes average tariff rates. "Current account" denotes current account restrictions on the proceeds from international trade in goods and services. "Networks" captures the degree of competition and liberalization and the quality of regulation in the electricity and telecommunications markets. "Agriculture" captures public intervention in the market for each country's main agricultural export commodity. "Capital Account" is an indicator of restrictions on financial credits and personal capital transactions for residents and financial credits for nonresidents. "Domestic finance" takes into account restrictions on the interest rate determination and the banking sector's competition, credit controls, and quality of supervision in the banking sector, as well as the degree of liberalization of securities markets. See appendix 2 for more details.

uses a set of growth spells identified by using the econometric methodology of Berg et al. (2012) to examine whether structural reforms accompany growth accelerations and whether reform reversals or the absence of reforms are associated with growth decelerations. Berg et al.'s methodology modifies the procedure first developed by Bai and Perron (1998) to determine sample-specific critical values for testing the presence of multiple structural breaks in a time series when both the total number and the location of breaks is unknown. Berg et al.'s procedure differs from Bai and Perron's approach in that it uses sample-specific critical values adjusted for the presence of heteroskedasticity and for small sample size. The last feature of this procedure is of particular relevance for our analysis, which is based on a data set with a time dimension 
WHICH REFORMS WORK AND UNDER WHAT INSTITUTIONAL ENVIRONMENT?

951

Figure 3. -Structural Reforms Indices by Constraint to the Executive LeVel
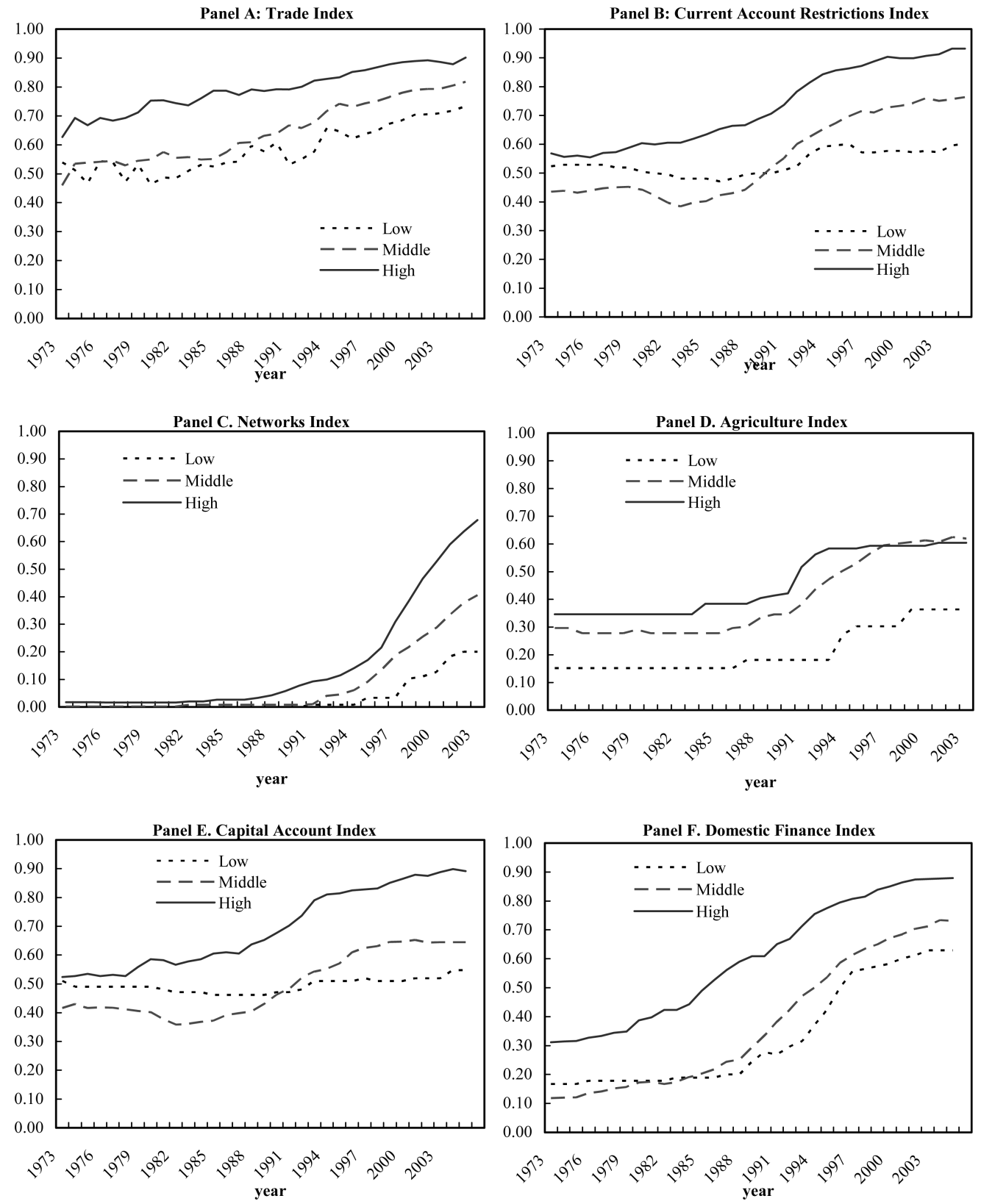

Source: Marshall et al. (2010) and authors' estimates.

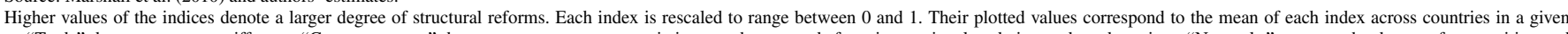

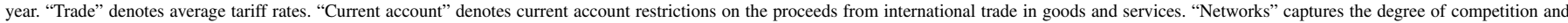

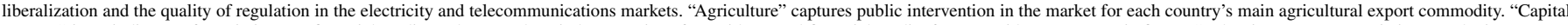

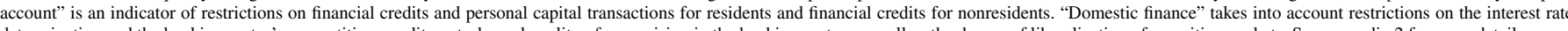

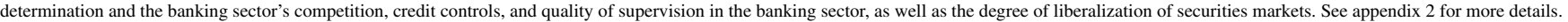

of about thirty years.12 (Appendix 3 lists all the episodes of up and down breaks in economic growth since 1960 that are detected by using this statistical methodology.)

Figures 4 and 5 plot the average level of the residuals, obtained through a panel regression of each index on country and year fixed effects, for a period starting five years before

12 Antoshin, Berg, and Souto (2008) provide a detailed description of these extensions and document how they improve both the power and the size properties of the test in applications with a small number of observations. a structural break in growth (denoted as 0 on the horizonal axis) and ending five years after it. The set of countries we rely on to plot the different graphs of figures 4 and 5 comprises those economies for which each sectoral reform index is available with continuity in the period starting three years before a break. In this manner, graphs of each indicator of structural reforms are drawn by using the same group of countries. The solid line depicts the evolution over time of each index's average residuals for countries that experience an up-break in economic growth, the dashed line for countries 

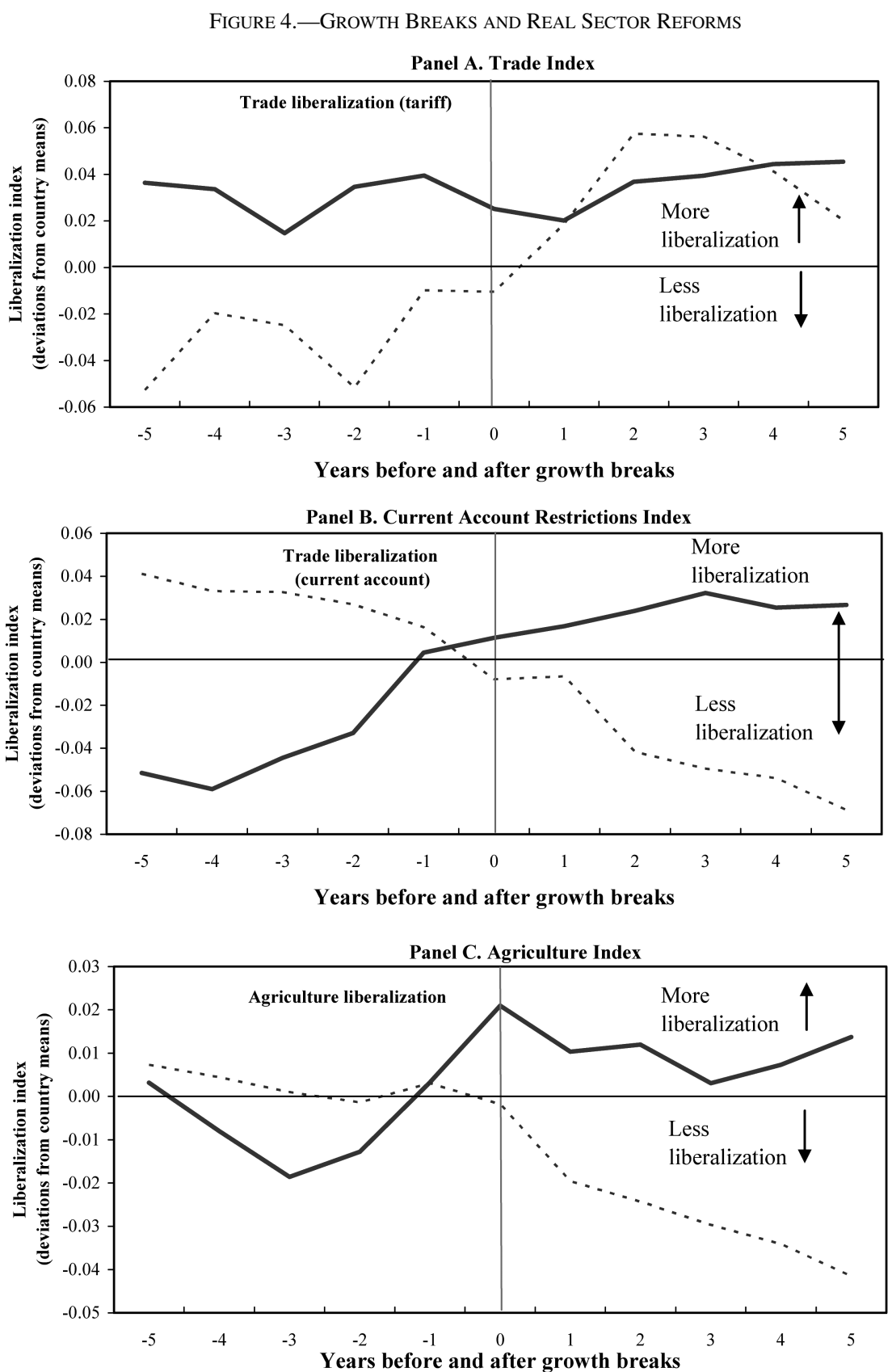

Source: Authors' estimates based on Penn World Tables, version 6.2.

The figures plot the (average) residuals of the reform indicators for a five-year period before and after the year of a break in economic growth, normalized to 0 on the horizontal axis. Residuals of the indices are obtained by regressing each index on country fixed effects (to remove country averages) and year fixed effects (to remove common trends). The solid line plots average residuals of the indices for countries that experience up-breaks in growth, the dashed one for countries that experience down-breaks in growth.

that have a down-break in economic growth. Given that panel regressions remove country- and year-specific averages of each index, a movement of the plotted average residual from below to above the 0 reference line on the vertical axis prior to an up-break (for example, in the case of the current account index, the solid line of the middle panel in figure 4) indicates that the reform index has gone from below the country average to above the country average prior to an up-break. The year-specific fixed effects effectively remove the global trend in each index so that, in practice, the country specific averages relative to which the plotted residuals are measured are trend-corrected. This means that the decline of the plotted residual lines around down-breaks (for example, in the case of the agriculture index, dashed line of bottom panel in figure 4) can indicate either reform reversals or lack of reform in a period when many other countries are reforming. ${ }^{13}$

${ }^{13}$ In figure 4, there is no chart for networks reform because of the few spells available after 1990 . 
Figure 5.-Growth BReaks AND FinANCIAL Sector ReForms
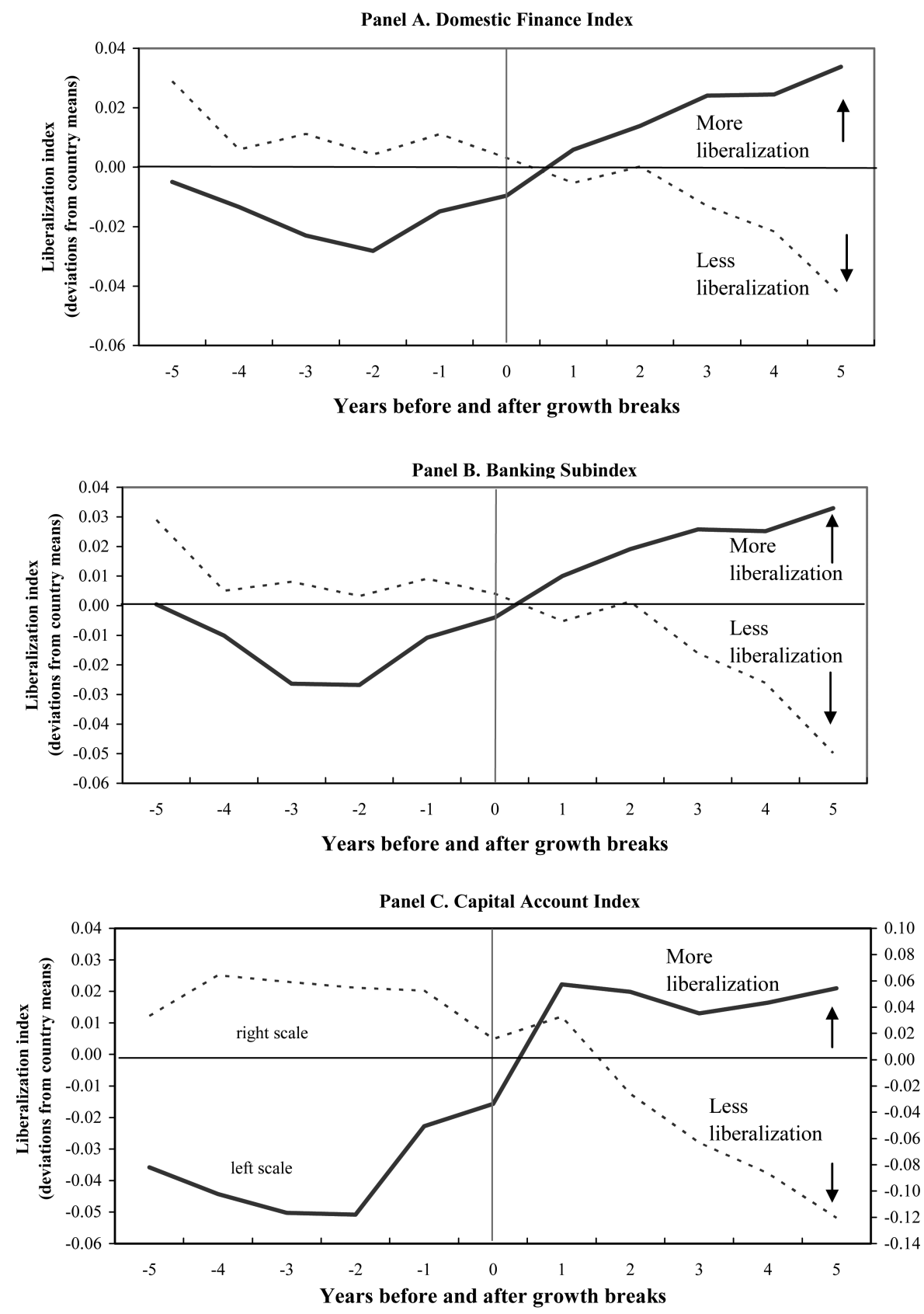

- Average liberalization index around upbreaks . . . . Average liberalization index around downbreaks

Source: Authors' estimates based on Penn World Tables, version 6.2.

The figures plot the (average) residuals of the reform indicators for a five-year period before and after the year of a break in economic growth, normalized to 0 on the horizontal axis. Residuals of the indices are obtained by regressing each index on country fixed effects (to remove country averages) and year fixed effects (to remove common trends). The solid line plots average residuals of the indices for countries that experience up-breaks in growth, the dashed one for countries that experience down-breaks in growth.

Among real-sector reforms (figure 4), liberalization of the current account and the agriculture sector are clearly associated with growth accelerations, with the indices improving about three years before the up-break and continuing on an upward trend afterward. Conversely, growth decelerations are associated with a tariff-based trade liberalization index below the country average (the 0 reference line for the vertical axis) and with deteriorating indices of current account liberalization and agriculture. Among financial sector reforms (figure 5), liberalization of the domestic financial sector and of the capital account is associated with growth accelerations. The banking component of the domestic financial sector index starts improving about two years before an upbreak. As in the case of most real sector indices, growth decelerations are associated with a downward trend of all financial indices, which tends to begin around the time of occurrence of the down-break and markedly continues afterward. 
Figure 6.-Reforms in the ReAl Sector And Growth Performance
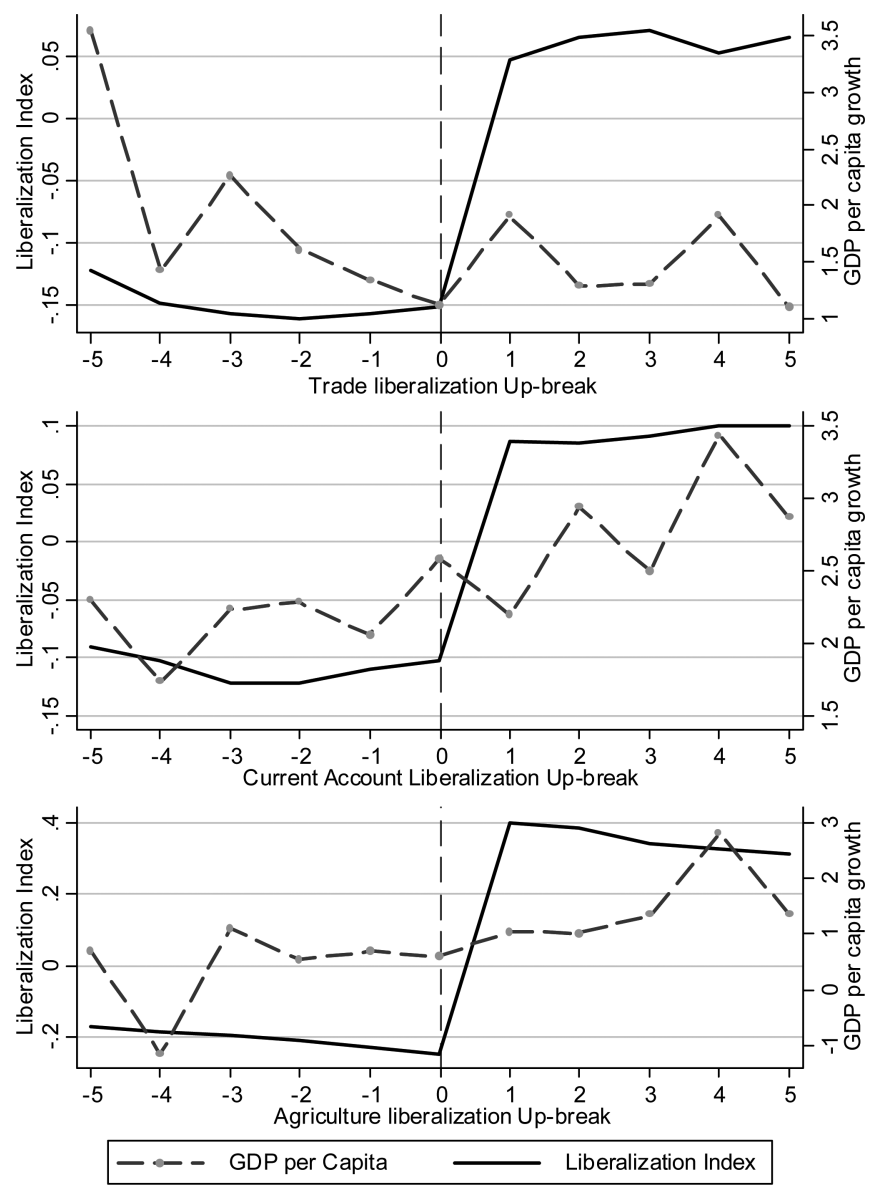

Source: Authors' estimates based on Penn World Tables, version 6.2.

The figures plot the average per capita GDP growth (dashed line) and the average reform index (solid line) during a five-year period before and after the year of an up-break in each reform index ( 0 on the horizontal axis).

Plotting the reform indices' average residuals around the time of an up-break in growth allows for a preliminary analysis of whether sustained periods of economic growth are associated with an increase in the different indices of sectorial reforms we consider. As a further step, we are interested in understanding more about the average growth pattern around the time a sharp increase in each index of structural reforms occurs. Figures 6 and 7 illustrate the average path of per capita GDP growth five years before and after an up-break in the reform indices, denoted as 0 on the horizontal axis of the graphs. The idea here is to see to what extent per capita GDP growth is associated with the main episodes of structural reforms that we are able to detect by using Berg et al.'s methodology. Among real sector reforms (figure 6), GDP growth shows a visible, albeit weak, trending up after substantial reforms of the current account and of the agricultural sector, while there is no such relation between growth and trade reforms. The association between growth and large financial reforms (especially banking) is much stronger, as shown in figure 7 . Interestingly, these observations are qualitatively consistent with those in the previous exercise.
Figure 7.- REForms in the FinANCIAL SeCtor AND Growth PERFormance
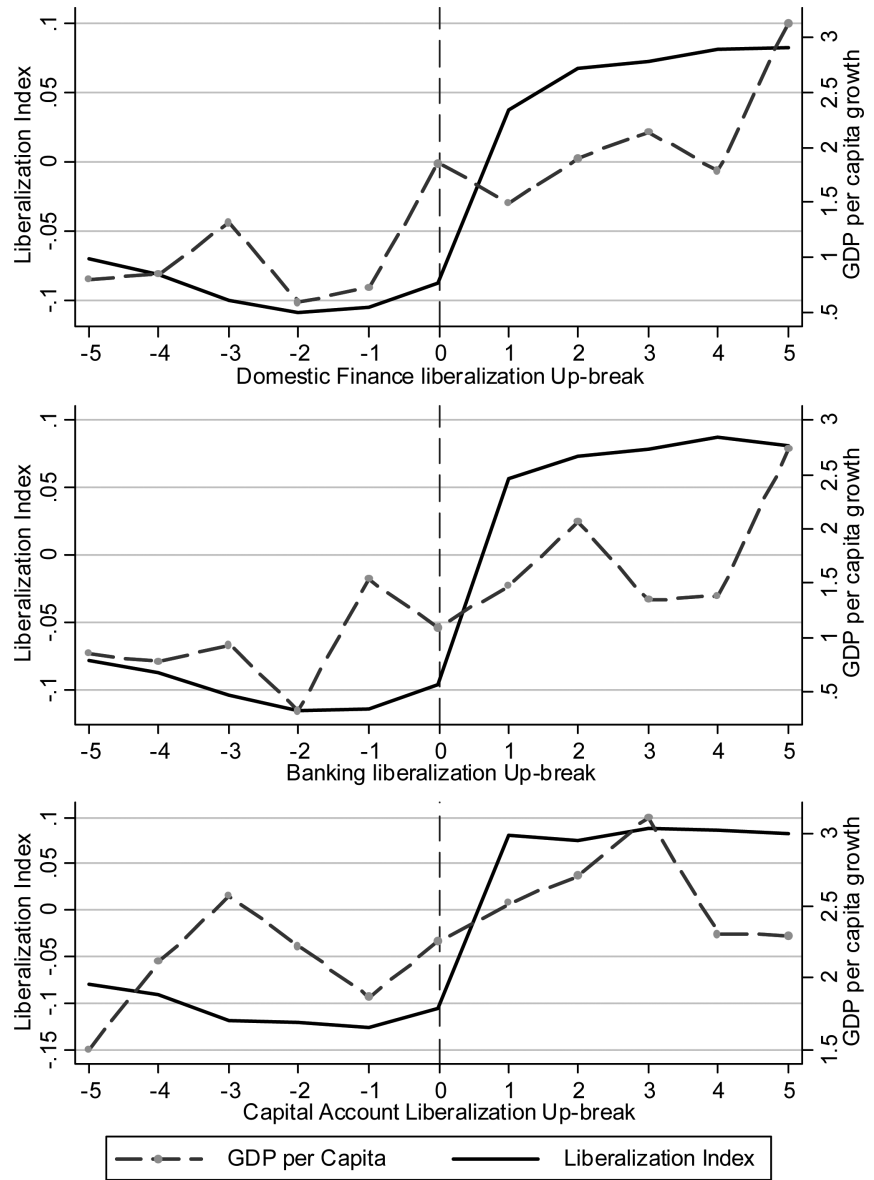

Source: Authors' estimates based on Penn World Tables, version 6.2.

The figures plot the average per capita GDP growth (dashed line) and the average reform index (solid line) during a five-year period before and after the year of an up-break in reform ( 0 on the horizontal axis)

So far we have shown how different reforms are associated with the average per capita GDP growth. Obviously, looking only at the average per capita growth may not be fully satisfactory as long as some processes of reforms can be misguided, mistimed, or simply poorly implemented. Figures 8 and 9 show evidence on how some real and financial sector liberalization attempts resulted in devastating growth outcomes with economies contracting at the rate of $5 \%$ or more per year. For instance, in the top panel of figure 8 on trade liberalization, ZIM88 indicates that two years after Zimbabwe's major reform steps to reduce tariffs in 1988, there was a sharp growth decline (annual per capita GDP growth declined around $12 \%$ ). Also, the bottom panel of figure 8 shows that three years after main reforms in the agricultural market, countries in South America, such as Argentina in the late 1970s, Brazil in the late 1980s, and Mexico in the early 1990s, experienced major growth downturns. Several subSaharan African countries went through a similar experience (for instance, Cameroon and Ethiopia in the early 1990s, and Malawi in the mid-1980s).

Under financial sector reforms, in the top panel of figure 9 on domestic finance liberalization, MOZ93 indicates that 


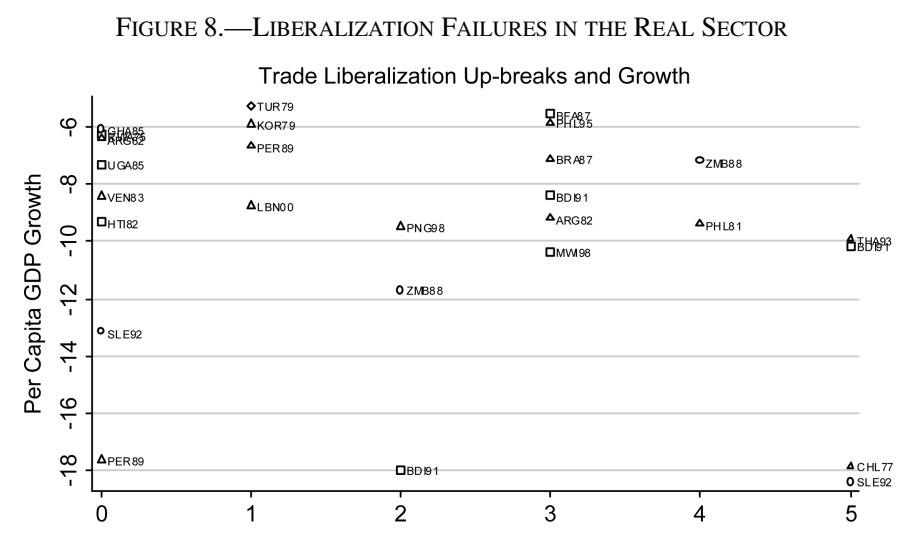

Figure 9.-_Liberalization FAILURES IN THE FinANCIAL SECTOR
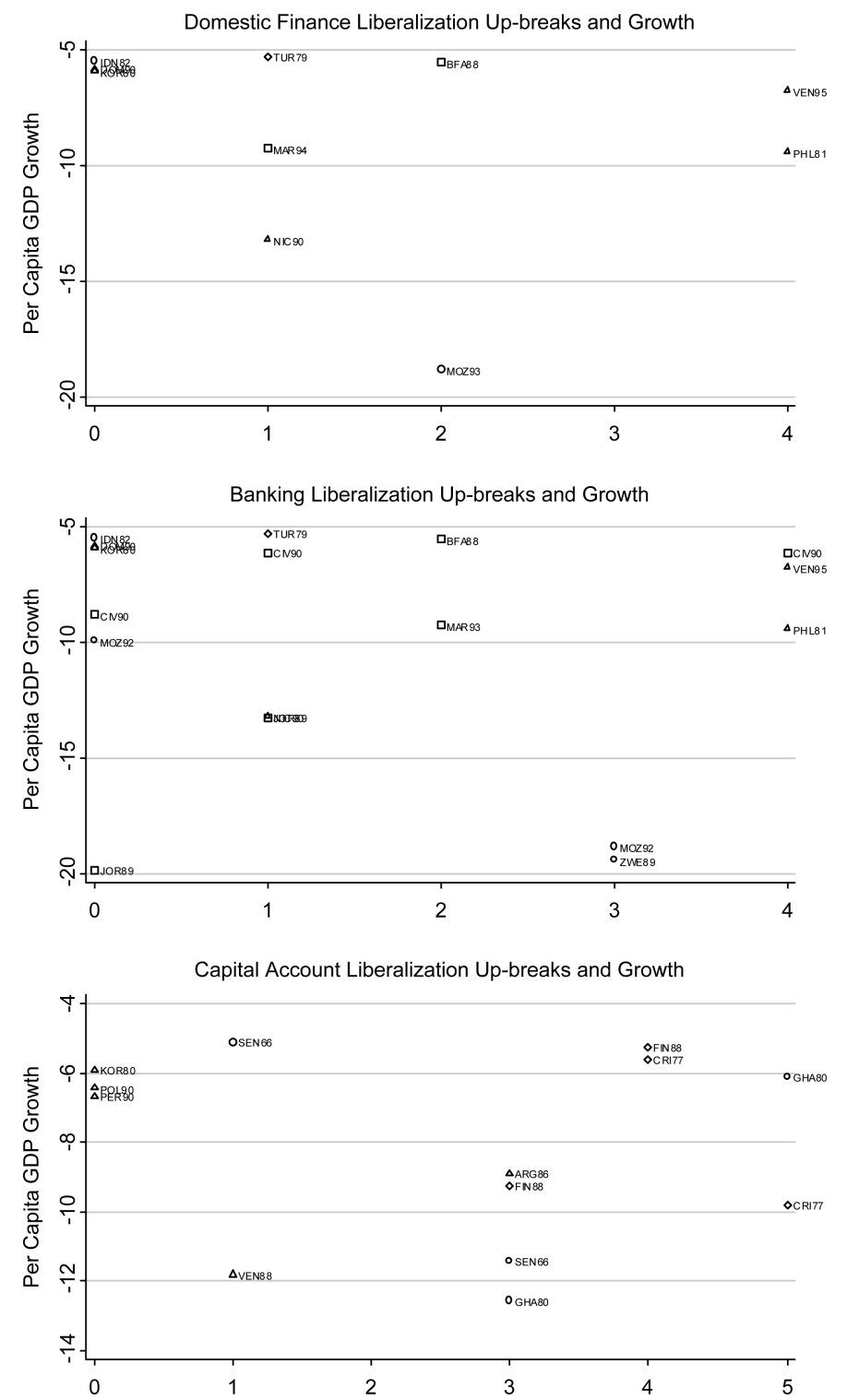

Source: Authors' estimates based on Penn World Tables, version 6.2, and Marshall et al. (2010).

The figures plot negative growth experiences (worse than -5 percent) from failed financial reforms. For example, in the top panel, on domestic finance liberalization, MOZ93 indicates that three years after Mozambique's major reform in 1993 to liberalize banking and securities markets sectors, there was a major growth downturn (annual per capita GDP declined by $20 \%$ ). The symbols next to the country names denote the level of constraints on the executive power from the Polity IV Project (2010) as follows: diamond (fourth quartile—highest institutional quality), triangle (third quartile), circle (second quartile), and square (first quartile-lowest institutional quality).

as Mauritanian, Mozambique, and Zimbabwe around 1990, were followed by devastating growth decelerations.

This evidence triggers the question, Why do potentially beneficial reforms turn into growth disasters? To take a first look at this question, we assign to each country name in figures 8 and 9 a symbol that denotes the level of institutional quality using the Polity IV index. We show that countries with a lower quality of institutions are more likely to experience growth failures after undertaking reforms. (It would be interesting to undertake a more careful and in-depth analysis of these results, perhaps focusing on country case studies
${ }^{14}$ Similar figures showing how reform up-breaks are associated with growth success stories (namely, per capita growth over 5\%) are available on request from the authors. three years after Mozambique's major reform steps to liberalize banking and securities market sectors in 1993, there was drastic growth decline (annual per capita GDP declined detect, across all reform indices, several cases in which the process of reforming sectors of the economy worked poorly. ${ }^{14}$ Also, substantial reforms undertaken in the banking sector by several low-income countries, (middle panel of figure 9), such
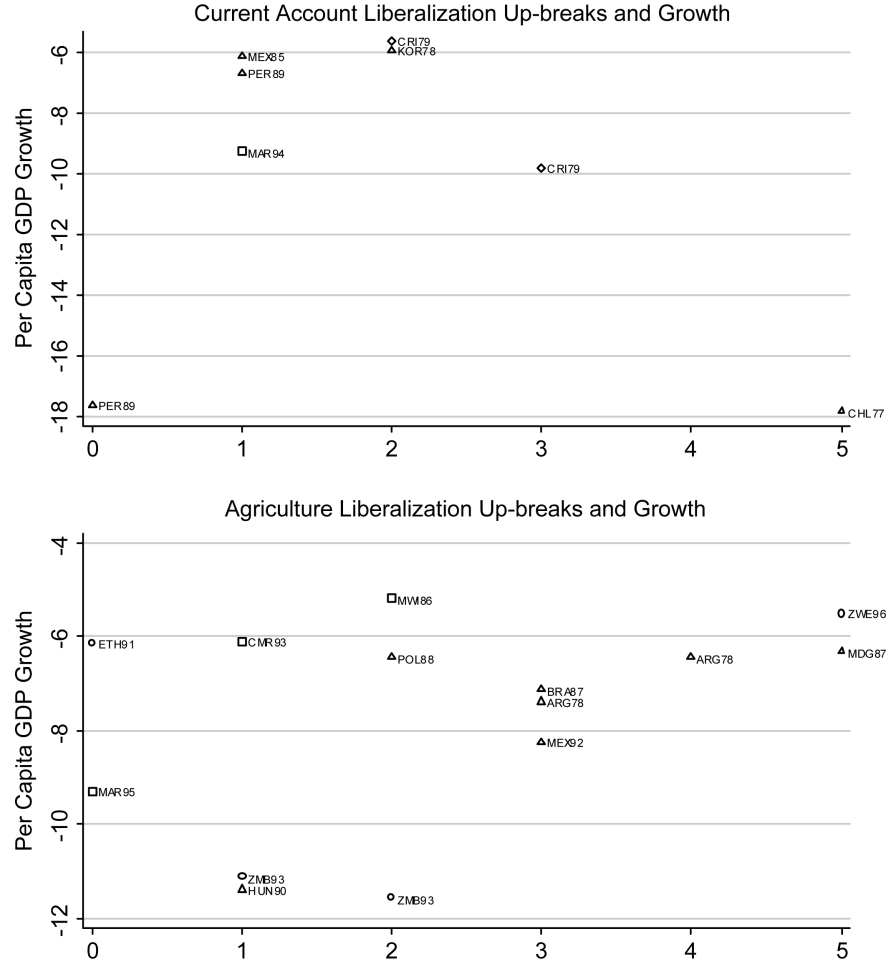

Source: Authors' estimates based on Penn World Tables, version 6.2, and Marshall et al. (2010).
The figures plot negative growth experiences (worse than -5 percent) from failed real reforms. For example in the top panel on trade liberalization, ZIM88 indicates that two years after Zimbabwe's majo by around $12 \%$ ). The symbols next to the country names denote the level of constraints on the executive power from the Polity IV Project (2010) as follows: diamond (fourth quartile- - highest institutional quality),
triangle (third quartile), circle (second quartile), and square (first quartile-lowest institutional quality). 
FigURE 10.-CRISES AND REFORM UPTICKS
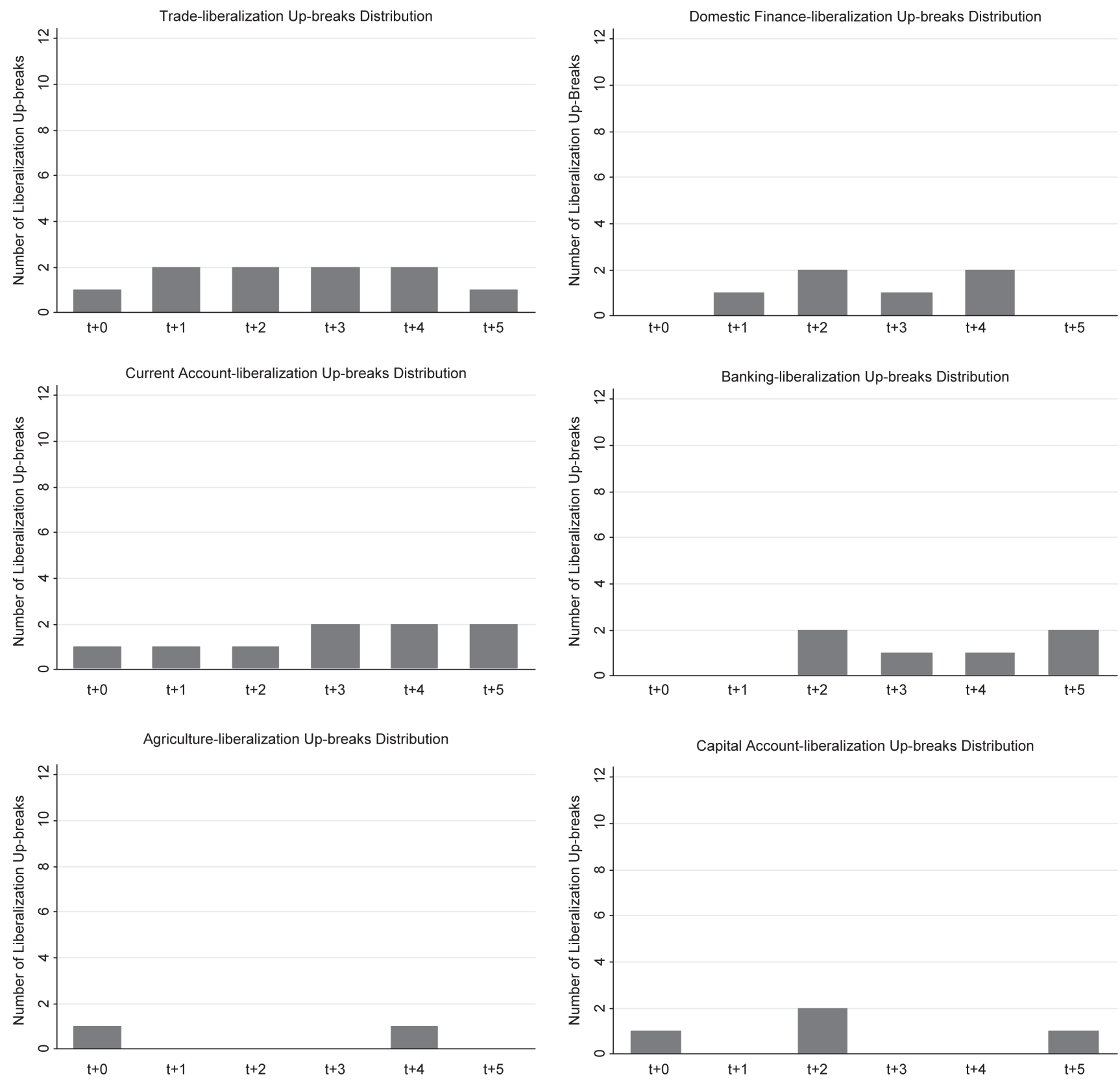

Source: Authors' estimates based on Penn World Tables, version 6.2.

The figure plots real and financial reform upticks following economic crises defined as growth down-breaks (severe and sustained growth decelerations).

and looking into these reform disasters, but this is beyond the scope of this paper).

Last but not least, we extend our analysis to consider the hypothesis that economic crises could lead to the adoption of structural reforms. That is, deteriorating economic conditions may facilitate major changes in economic policies (see, among the others, Drazen, 2000, and Drazen \& Easterly, 2001). This could be analyzed directly here by looking at whether growth down-breaks stimulate subsequent liberalizations upticks. Figure 10 shows some evidence in favor of the crisis-reforms hypothesis where major reform attempts emerge a few years after a growth collapse. In the real sector, several cases of trade and current account reforms emerged after a growth collapse. The same is observed for domestic finance, and specifically banking reforms, albeit with some lag.

\section{B. Reforms and Growth Trends: Baseline Regressions}

In this section we provide econometric evidence based on growth regressions about the relationship between structural 
Table 1.-Baseline Growth Regressions

\begin{tabular}{|c|c|c|c|c|c|c|c|c|c|c|}
\hline $\begin{array}{l}\text { Dependent Variable: } \\
\text { lnGDP }(t)-\operatorname{lnGDP}(t-1)\end{array}$ & (1) & (2) & (3) & (4) & $(5)$ & (6) & (7) & (8) & (9) & (10) \\
\hline \multicolumn{11}{|l|}{ Real sector reforms } \\
\hline Trade $(t-1)$ & $\begin{array}{r}0.019 * \\
(0.010)\end{array}$ & & & & & & & & & \\
\hline Current account $(t-1)$ & & $\begin{array}{l}0.033^{* * *} \\
(0.008)\end{array}$ & & & & & & & & \\
\hline Agriculture $(t-1)$ & & & $\begin{array}{l}0.018^{* *} \\
(0.008)\end{array}$ & & & & & & & \\
\hline Network $(t-1)$ & & & & $\begin{array}{c}0.004 \\
(0.009)\end{array}$ & & & & & & \\
\hline \multicolumn{11}{|l|}{ Financial sector reforms } \\
\hline Domestic finance $(t-1)$ & & & & & $\begin{array}{l}0.064^{* * *} \\
(0.014)\end{array}$ & & & & & \\
\hline Banking $(t-1)$ & & & & & & $\begin{array}{l}0.050^{* * *} \\
(0.012)\end{array}$ & & & & \\
\hline Securities $(t-1)$ & & & & & & & $\begin{array}{l}0.037^{* * *} \\
(0.008)\end{array}$ & & & \\
\hline Capital $(t-1)$ & & & & & & & & $\begin{array}{l}0.021^{* *} \\
(0.009)\end{array}$ & & \\
\hline Capital (resident) $(t-1)$ & & & & & & & & & $\begin{array}{l}0.015^{* *} \\
(0.007)\end{array}$ & \\
\hline Capital (nonresident) $(t-1)$ & & & & & & & & & & $\begin{array}{c}0.016 * \\
(0.008)\end{array}$ \\
\hline $\operatorname{lnGDP}(t-1)$ & $\begin{array}{l}-0.048^{* * *} \\
(0.007)\end{array}$ & $\begin{array}{l}-0.051^{* * *} \\
(0.009)\end{array}$ & $\begin{array}{l}-0.036^{* * *} \\
(0.007)\end{array}$ & $\begin{array}{l}-0.045^{* * *} \\
(0.008)\end{array}$ & $\begin{array}{l}-0.042^{* * *} \\
(0.008)\end{array}$ & $\begin{array}{l}-0.041^{* * *} \\
(0.008)\end{array}$ & $\begin{array}{l}-0.047^{* * *} \\
(0.008)\end{array}$ & $\begin{array}{l}-0.051^{* * *} \\
(0.009)\end{array}$ & $\begin{array}{l}-0.049^{* * *} \\
(0.009)\end{array}$ & $\begin{array}{l}-0.051^{* * *} \\
(0.009)\end{array}$ \\
\hline Observations & 3,418 & 3,530 & 3,390 & 3,796 & 2,653 & 2,653 & 2,653 & 3,530 & 3,556 & 3,530 \\
\hline$R^{2}$ & 0.194 & 0.141 & 0.169 & 0.148 & 0.199 & 0.194 & 0.196 & 0.139 & 0.137 & 0.138 \\
\hline
\end{tabular}

reforms and economic growth. We estimate through ordinary least squares (OLS) the following specification:

$$
\begin{aligned}
\ln G D P_{i, t}-\ln G D P_{i, t-1} & =a_{0}+a_{1} \ln G D P_{i, t-1} \\
& +a_{2} \text { Reform }_{i, t-1}+\eta_{i}+\delta_{t}+\varepsilon_{i t},
\end{aligned}
$$

in which the per capita GDP growth in country $i$ at period $t$ is regressed on the log of a one-year lag of per capita GDP and a one-year lag of each indicator of structural reforms $\left(\right.$ Reform $\left._{i, t-1}\right)$. A full set of country and year fixed effects denoted by the terms $\eta_{i}$ and $\delta_{t}$, respectively, is included in the model; $\varepsilon_{i t}$ represents the error term. By including country fixed effects, we control for any country time-invariant characteristic (such as geographical location, historical legacies, and legal origins) that could affect both the adoption of structural reforms and per capita income growth. Baseline estimates are obtained by using yearly data for the period 1973 to 2006.15

Estimates from baseline specification (1) are reported in table 1. With the exception of reforms in the electricity and telecommunications markets (network) the coefficient estimates of all the remaining indices of structural reforms are positive and statistically significant at conventional levels. As it concerns reforms of the real sectors of the economy, the coefficient estimate for the current account has the largest

\footnotetext{
15 Although data for some indicators of structural reforms go back to the 1960 s, we chose to base our estimation on data starting from 1973, given their better quality.
}

magnitude and is statistically significant at the $1 \%$ level. The coefficients of international trade and agricultural market reforms have a smaller magnitude and are statistically significant at the $10 \%$ and $5 \%$ levels, respectively. The overall indicator of reforms of the domestic financial market (the composite index of six financial sectors' subindices) shows the largest positive coefficient magnitude and is also precisely estimated. Reforms of the banking and security sectors also show positive and statistically significant coefficient estimates, with the coefficient magnitude of the second variable being smaller than the first one. The coefficient estimates of the three indices of the external capital account openness are also positive and statistically significant, though smaller in magnitude and less precisely estimated than the ones pertaining to the domestic financial sector. It may be surprising that the electricity and telecommunications markets do not show a positive association with growth, but as subsequent robustness analysis shows, this result is driven by the fact that network reforms have started much later than other reforms (figure 1 shows that the relevant index is close to 0 from 1973 to the end of the 1980s before showing a steep and almost linear trend for the later period).

To gauge the size of the estimated correlation between structural reforms and an increase in per capita income, we focus on long-term multipliers, which take into account the different dynamics of each reform and make their association with growth comparable across the different kinds of reforms. Specifically, a full liberalization of the current account, which corresponds to a discrete jump of its index from the minimum 
of 0 to the maximum of 1 , is associated with an estimated increase of the output per capita by almost $65 \%$ in the long run. The largest estimated coefficient refers to the reform of the domestic financial market: a discrete jump of this indicator from 0 would more than double output per capita in the long run. ${ }^{16}$

It is also interesting to note that although the "breaks" analysis of the previous section is concerned with average spells rather than average estimated coefficients obtained by the current regression analysis, results from the two exercises are broadly consistent, showing positive associations between current account and domestic financial reforms and growth.

Motivated by recent contributions to the literature, we examine possible heterogeneity of the association between reforms and growth in two dimensions: the distance from the technological frontier and the quality of institutions.

\section{Reforms; Distance from the Technological Frontier and Growth}

An alternative to the standard neoclassical growth model is the Schumpeterian growth theory, which emphasizes the process of creative destruction. ${ }^{17}$ A key implication of the literature motivated by this approach is that the process of economic development is influenced by a country's income difference from that of the countries at the world technology frontier. One of the most relevant questions in this literature is how quickly low-income countries can close their income gap with the economies at the technological frontier. The distance from the frontier therefore becomes a key economic dimension according to which policies aimed at fostering economic growth should be designed and implemented.

As stressed, for instance, in Acemoglu, Aghion, and Zilibotti (2006), the main cause of growth for economies far from the technological frontier is the adoption of already existing technologies. As a country approaches the technological frontier, the main force behind the process of economic growth becomes innovation. According to these authors, the design of specific pro-growth policies should critically take into consideration the different stages of economic development in different countries. Aghion and Howitt (2006) analyze in depth the case of education, arguing that primary and secondary education matters more for a country's ability to imitate existing technologies, while tertiary

\footnotetext{
${ }^{16}$ The inverse of (minus) the coefficient of the log of a one-year lag of per capita GDP is the term by which the estimated coefficient of each indicator of reforms is multiplied to obtain the long-run association between a discrete jump of each index of reforms from 0 to 1 and the increase in per capita income.

${ }^{17}$ The process of creative destruction was pioneered in the writings of Joseph Schumpeter $(1928,1942)$ and refers to the endogenous introduction of new products and processes that inevitably eliminates some of the existing products and processes. Schumpeterian growth theory has been revived and formally modeled by Aghion and Howitt (1992).
}

education is more important for a country's ability to innovate. ${ }^{18}$ As countries catch up with the technology frontier, tertiary education should be more relevant for growth than primary and secondary education. ${ }^{19}$ In complementary work, Aghion et al. (2009) show that close to the technological frontier in addition to the education level, product market rigidities and employment protection legislation would be significantly related to TFP growth.

To test whether the association between reforms and growth nonlinearly depends on the distance to the technology frontier, we group the countries in our sample in quartiles according to this dimension. Specifically, we use the ratio of each country's per capita GDP to that of the United States as a proxy for its distance to the technology frontier in a given year. For each country we then compute the average distance to the frontier over the years in our sample, according to which economies are assigned to different quartiles. For each quartile, we estimate an econometric model similar to equation (1). The only difference is that we include a one-year lag of the ratio of each country's per capita GDP to that of the United States instead of a one-year lag of the log of per capita income. Consistent with the existing literature, this is done to account for the process of convergence to the technology frontier. As in the previous section, one indicator of reform per time is included in the specification.

Our findings are summarized in table 2 , which is organized as follows. In each of columns 1 to 10 , we report the coefficients and the standard errors (clustered at the country level) estimated for each indicator of reforms across the different quartiles. The bottom row reports the $p$-value of the test of the equality of the coefficient estimates across the different quartiles. We find no evidence of a significant association between reforms and growth for countries in the first quartile (countries most distant from the technology frontier). With the exception of openness to international trade (as measured by the average tariff rates) and reforms in the networks sector, all the remaining indices display instead a statistically significant and positive coefficient estimate in the second quartile. The domestic financial sector and the banking sector maintain a positive and statistically significant coefficient estimate, also in the third quartile. Current account and securities market reforms display an interesting nonlinear correlation with economic growth. Their estimated

\footnotetext{
${ }^{18}$ The analysis of education policies in Aghion and Howitt $(2005,2006)$ is based also on work by Vandenbussche, Aghion, and Meghir (2006) and Aghion et al. (2005).

${ }^{19}$ Aghion and Howitt (2006) combine insights from Nelson and Phelps (1966) and Acemoglu et al. (2006). Nelson and Phelps model an economy where productivity growth is a function of domestic human capital and the distance from the frontier technology growing over time at an exogenous rate. A higher stock of human capital fosters growth by facilitating the catching up with the technological frontier. Similar to Acemoglu et al. (2006), Aghion and Howitt (2006) show that productivity growth can be generated by imitating existing technology or by innovating. The relative importance of innovation increases as a country gets closer to the technological frontier. Moreover, investing in higher education should produce a larger effect on a country's ability to produce leading-edge innovation, while investing in primary and secondary education should exert a larger impact on a country's ability to implement existing technologies.
} 


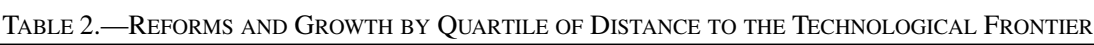

\begin{tabular}{|c|c|c|c|c|c|c|c|c|c|c|}
\hline & $\begin{array}{l}(1) \\
\text { Trade }\end{array}$ & $\begin{array}{c}(2) \\
\text { Current } \\
\text { Account }\end{array}$ & $\begin{array}{c}\text { (3) } \\
\text { Agriculture }\end{array}$ & $\begin{array}{c}\text { (4) } \\
\text { Network }\end{array}$ & $\begin{array}{c}(5) \\
\text { Domestic } \\
\text { Finance }\end{array}$ & $\begin{array}{c}\text { (6) } \\
\text { Banking }\end{array}$ & $\begin{array}{c}(7) \\
\text { Securities }\end{array}$ & $\begin{array}{c}(8) \\
\text { Capital }\end{array}$ & $\begin{array}{c}(9) \\
\text { Capital } \\
\text { (resident) }\end{array}$ & $\begin{array}{c}(10) \\
\text { Capital } \\
\text { (nonresident) }\end{array}$ \\
\hline First quartile & $\begin{array}{c}0.041 \\
(0.025)\end{array}$ & $\begin{array}{c}0.028 \\
(0.022)\end{array}$ & $\begin{array}{c}0.010 \\
(0.016)\end{array}$ & $\begin{array}{c}0.025 \\
(0.022)\end{array}$ & $\begin{array}{c}0.026 \\
(0.044)\end{array}$ & $\begin{array}{c}0.017 \\
(0.040)\end{array}$ & $\begin{array}{c}0.030 \\
(0.024)\end{array}$ & $\begin{array}{c}0.006 \\
(0.019)\end{array}$ & $\begin{array}{c}0.016 \\
(0.016)\end{array}$ & $\begin{array}{r}-0.008 \\
(0.019)\end{array}$ \\
\hline Second quartile & $\begin{array}{c}0.027 \\
(0.023)\end{array}$ & $\begin{array}{l}0.054^{* * *} \\
(0.016)\end{array}$ & $\begin{array}{l}0.041^{* *} \\
(0.018)\end{array}$ & $\begin{array}{c}0.006 \\
(0.026)\end{array}$ & $\begin{array}{l}0.109^{* * *} \\
(0.030)\end{array}$ & $\begin{array}{l}0.083^{* * *} \\
(0.026)\end{array}$ & $\begin{array}{l}0.075^{* * *} \\
(0.020)\end{array}$ & $\begin{array}{l}0.038^{* * *} \\
(0.013)\end{array}$ & $\begin{array}{r}0.022^{*} \\
(0.012)\end{array}$ & $\begin{array}{l}0.030^{* *} \\
(0.012)\end{array}$ \\
\hline Third quartile & $\begin{array}{r}-0.005 \\
(0.016)\end{array}$ & $\begin{array}{c}-0.003 \\
(0.014)\end{array}$ & $\begin{array}{c}0.007 \\
(0.013)\end{array}$ & $\begin{array}{c}0.008 \\
(0.022)\end{array}$ & $\begin{array}{l}0.114^{* * *} \\
(0.031)\end{array}$ & $\begin{array}{l}0.101^{* * *} \\
(0.027)\end{array}$ & $\begin{array}{c}0.030 \\
(0.020)\end{array}$ & $\begin{array}{c}-0.004 \\
(0.015)\end{array}$ & $\begin{array}{c}0.002 \\
(0.010)\end{array}$ & $\begin{array}{r}-0.009 \\
(0.016)\end{array}$ \\
\hline Fourth quartile & $\begin{array}{c}0.024 \\
(0.016)\end{array}$ & $\begin{array}{l}0.037^{* *} \\
(0.014)\end{array}$ & $\begin{array}{c}0.000 \\
(0.014)\end{array}$ & $\begin{array}{l}0.003 \\
(0.014)\end{array}$ & $\begin{array}{c}0.004 \\
(0.012)\end{array}$ & $\begin{array}{c}-0.005 \\
(0.010)\end{array}$ & $\begin{array}{l}0.019^{* *} \\
(0.007)\end{array}$ & $\begin{array}{c}0.032 \\
(0.019)\end{array}$ & $\begin{array}{c}0.024 \\
(0.017)\end{array}$ & $\begin{array}{r}0.028^{*} \\
(0.015)\end{array}$ \\
\hline $\begin{array}{l}\text { Test equation coefficient } \\
\quad(p \text {-value })\end{array}$ & 0.3609 & 0.0537 & 0.3444 & 0.8620 & 0.0004 & 0.0003 & 0.0845 & 0.1660 & 0.5131 & 0.1185 \\
\hline
\end{tabular}

Sources: Penn World Tables version 6.2 and authors' estimates.

Coefficients and robust standard errors clustered at the country level (in parentheses) are obtained for each quartile by OLS estimates of an equation in which each country's growth rate of per capita GDP at time $t$ is regressed on one-year lag of each indicator of reforms per time and on one-year lag of the ratio of each country's per capita GDP to that of the United States. All specifications include country and year fixed effects. The $p$-value of the test of equality of the coefficient estimates across quartiles is reported in the bottom row of the table. Annual data over 1973-2006 when available. GDP in real terms and PPP adjusted. Significant at $* 10 \%, * * 5 \%$, and $* * * 1 \%$

coefficients are positive and statistically significant at conventional levels also in the fourth quartile, even if the magnitude of the coefficients is smaller compared to the second quartile. The coefficient estimates for current account and domestic financial reform (and its banking and securities subcomponents) are statistically different from each other across the different quartiles. Finally, the positive coefficient estimate of capital account openness for nonresidents is also statistically significant in the fourth quartile (countries closest to the technology frontier). Its coefficient estimates nevertheless are not statistically different from each other across quartiles.

The lack of a significant association between reforms and growth for countries most distant from the technology frontier (first quartile) may be explained by considering that these economies are likely to have a poor institutional environment, in which case we find scattered evidence about the relevance of reforms for growth (for details, see the next section). On the other hand, that reduction of restrictions on current account reforms and policies that encourage the formation of bonds and securities' markets have a significant association with growth for countries closest to the frontier (fourth quartile), and is suggestive of the idea that they may favor innovationled growth through openness to international competition and the availability of financial instruments useful for financing the innovation process (consistent with Aghion, Howitt, $\&$ Mayer-Foulkes, 2005). Perhaps more interesting are the results for countries neither too far from nor too close to the frontier (second and third quartiles). Several reforms, and specifically those of the domestic financial market, seem to work better in countries fighting their way toward the status of emerging or even advanced economies. Relaxing market constraints through reforms of the domestic financial market and of the banking sectors may be more valuable in countries that could benefit the most from large increases in private credit and investment. In such developing economies, domestic financial reforms can facilitate the transfer and financing of existing technologies, contributing to a higher TFP and growth.

\section{Reforms: Institutions and Growth}

In this section we examine whether a country's broad institutional environment affects the way in which reforms promote growth. On the basis of recent literature, we focus on two possible relevant dimensions of the institutional environment. First, we consider the quality of the political institutions, as captured by the degree of constraints imposed on the executive power. Acemoglu et al. (2008) suggest that reforms can be expected to be more effective in countries characterized by an intermediate level of constraints on the executive power. Second, on the basis of the findings of Acemoglu et al. (2001), we investigate whether the average protection against the risk of expropriation influences the extent to which structural reforms matter for a country's economic performance.

To test whether the association between reforms and growth is heterogeneous across each of these two institutional dimensions, we adopt an approach similar to the previous section. We compute each country's average level of constraints on the executive power (taken from the Polity IV project) over the years in our sample and, according to this dimension, assign the countries in our sample to different quartiles. ${ }^{20} \mathrm{We}$ also group the countries in our sample in a second set of quartiles by using the variable that measures the average protection against expropriation risk from Acemoglu et al. (2001). ${ }^{21}$ The regression specification used is the same as in equation (1) that now incorporates these institutional measures across different quartiles.

${ }^{20}$ See Marshall et al. (2010). This variable assumes values that range from 1 , when there are no regular limitations on the executive power, to 7 , when other political bodies have equal or more power than the executive. It assumes also values of $-88,-77,-66$, which denote, respectively, periods of transition, interregnum, and interruption. We turn such values to missing when computing the sample mean of the constraints on the executive power.

${ }^{21}$ As Acemoglu et al. (2001, p. 1397) explain, this variable, originally elaborated by the Political Risk Services, measures the "risk of expropriation of private foreign investment by government." It takes values from 0 to 10 , with higher values denoting a lower risk of being expropriated, and for each country is constructed as the average value over the years 1985 to 1995 . 
TABLe 3.-Reforms and Growth by Quartile of Constraints on the EXecutive Power

\begin{tabular}{|c|c|c|c|c|c|c|c|c|c|c|}
\hline & $\begin{array}{l}\text { (1) } \\
\text { Trade }\end{array}$ & $\begin{array}{c}\text { (2) } \\
\text { Current } \\
\text { Account }\end{array}$ & $\begin{array}{c}\text { (3) } \\
\text { Agriculture }\end{array}$ & $\begin{array}{c}\text { (4) } \\
\text { Network }\end{array}$ & $\begin{array}{c}(5) \\
\text { Domestic } \\
\text { Finance }\end{array}$ & $\begin{array}{c}(6) \\
\text { Banking }\end{array}$ & $\begin{array}{c}(7) \\
\text { Securities }\end{array}$ & $\begin{array}{c}(8) \\
\text { Capital }\end{array}$ & $\begin{array}{c}(9) \\
\text { Capital } \\
\text { (resident) }\end{array}$ & $\begin{array}{c}(10) \\
\text { Capital } \\
\text { (nonresident) }\end{array}$ \\
\hline First quartile & $\begin{array}{r}0.051^{*} \\
(0.029)\end{array}$ & $\begin{array}{c}0.085^{* *} \\
(0.034)\end{array}$ & $\begin{array}{c}0.010 \\
(0.028)\end{array}$ & $\begin{array}{c}-0.026 \\
(0.047)\end{array}$ & $\begin{array}{c}0.125 \\
(0.091)\end{array}$ & $\begin{array}{c}0.090 \\
(0.070)\end{array}$ & $\begin{array}{c}0.055 \\
(0.051)\end{array}$ & $\begin{array}{c}0.041 \\
(0.027)\end{array}$ & $\begin{array}{c}0.024 \\
(0.025)\end{array}$ & $\begin{array}{c}0.036 \\
(0.026)\end{array}$ \\
\hline Second quartile & $\begin{array}{c}0.011 \\
(0.021)\end{array}$ & $\begin{array}{c}0.024 \\
(0.023)\end{array}$ & $\begin{array}{c}0.024 \\
(0.019)\end{array}$ & $\begin{array}{c}-0.041 \\
(0.027)\end{array}$ & $\begin{array}{l}0.096^{* * *} \\
(0.031)\end{array}$ & $\begin{array}{l}0.075^{* *} \\
(0.027)\end{array}$ & $\begin{array}{c}0.041^{*} \\
(0.023)\end{array}$ & $\begin{array}{r}-0.010 \\
(0.018)\end{array}$ & $\begin{array}{c}-0.002 \\
(0.013)\end{array}$ & $\begin{array}{c}-0.015 \\
(0.019)\end{array}$ \\
\hline Thrid quartile & $\begin{array}{c}0.022 \\
(0.019)\end{array}$ & $\begin{array}{c}0.019^{*} \\
(0.011)\end{array}$ & $\begin{array}{c}0.020 \\
(0.012)\end{array}$ & $\begin{array}{r}0.033^{*} \\
(0.017)\end{array}$ & $\begin{array}{l}0.080^{* * *} \\
(0.024)\end{array}$ & $\begin{array}{l}0.066^{* * *} \\
(0.023)\end{array}$ & $\begin{array}{l}0.031^{* *} \\
(0.012)\end{array}$ & $\begin{array}{c}0.020 \\
(0.012)\end{array}$ & $\begin{array}{c}0.016 \\
(0.010)\end{array}$ & $\begin{array}{c}0.015 \\
(0.011)\end{array}$ \\
\hline Fourth quartile & $\begin{array}{c}0.001 \\
(0.010)\end{array}$ & $\begin{array}{c}0.020 \\
(0.013)\end{array}$ & $\begin{array}{c}0.021 \\
(0.015)\end{array}$ & $\begin{array}{c}-0.002 \\
(0.014)\end{array}$ & $\begin{array}{c}0.023 \\
(0.017)\end{array}$ & $\begin{array}{c}0.009 \\
(0.013)\end{array}$ & $\begin{array}{l}0.031^{* * *} \\
(0.010)\end{array}$ & $\begin{array}{c}0.017 \\
(0.017)\end{array}$ & $\begin{array}{c}0.009 \\
(0.014)\end{array}$ & $\begin{array}{c}0.018 \\
(0.013)\end{array}$ \\
\hline $\begin{array}{l}\text { Test equation coefficient } \\
\text { ( } p \text {-value) }\end{array}$ & 0.3507 & 0.2966 & 0.9808 & 0.0934 & 0.0704 & 0.0434 & 0.9358 & 0.3801 & 0.6675 & 0.3652 \\
\hline
\end{tabular}

Sources: Penn World Tables version 6.2, Marshall et al. (2010), and authors' estimates.

Coefficients and robust standard errors clustered at country level (in parentheses) are obtained for each quartile by OLS estimates of an equation in which each country's growth rate of per capita GDP at time $t$ is regressed on one-year lag of each indicator of reforms per time and on one-year lag of the log of per capita GDP. All specifications include country and year fixed effects. The $p$-value of the test of equality of the coefficient estimates across quartiles is reported in the bottom row of the table. Annual data over 1973-2006 when available. GDP in real terms and PPP adjusted. Significant at $* 10 \%, * * 5 \%$, and $* * * 1 \%$.

Table 4.--Reforms and Growth by Quartile of AVErage Protection Against Risk of Expropriation

\begin{tabular}{|c|c|c|c|c|c|c|c|c|c|c|}
\hline & $\begin{array}{l}(1) \\
\text { Trade }\end{array}$ & $\begin{array}{c}(2) \\
\text { Current } \\
\text { Account }\end{array}$ & $\begin{array}{c}\text { (3) } \\
\text { Agriculture }\end{array}$ & $\begin{array}{c}\text { (4) } \\
\text { Network }\end{array}$ & $\begin{array}{c}(5) \\
\text { Domestic } \\
\text { Finance }\end{array}$ & $\begin{array}{c}(6) \\
\text { Banking }\end{array}$ & $\begin{array}{c}(7) \\
\text { Securities }\end{array}$ & $\begin{array}{c}(8) \\
\text { Capital }\end{array}$ & $\begin{array}{c}\text { (9) } \\
\text { Capital } \\
\text { (resident) }\end{array}$ & $\begin{array}{c}(10) \\
\text { Capital } \\
\text { (nonresident) }\end{array}$ \\
\hline First quartile & $\begin{array}{c}0.038 \\
(0.025)\end{array}$ & $\begin{array}{c}0.041 \\
(0.026)\end{array}$ & $\begin{array}{c}0.011 \\
(0.013)\end{array}$ & $\begin{array}{c}0.035 \\
(0.023)\end{array}$ & $\begin{array}{c}-0.021 \\
(0.043)\end{array}$ & $\begin{array}{c}-0.025 \\
(0.038)\end{array}$ & $\begin{array}{c}0.019 \\
(0.027)\end{array}$ & $\begin{array}{r}0.038^{*} \\
(0.019)\end{array}$ & $\begin{array}{c}0.025 \\
(0.017)\end{array}$ & $\begin{array}{r}0.034^{*} \\
(0.019)\end{array}$ \\
\hline Second quartile & $\begin{array}{c}0.019 \\
(0.019)\end{array}$ & $\begin{array}{c}0.024 \\
(0.020)\end{array}$ & $\begin{array}{c}0.014 \\
(0.011)\end{array}$ & $\begin{array}{c}-0.003 \\
(0.027)\end{array}$ & $\begin{array}{c}0.046 \\
(0.031)\end{array}$ & $\begin{array}{c}0.041 \\
(0.031)\end{array}$ & $\begin{array}{c}0.010 \\
(0.017)\end{array}$ & $\begin{array}{c}-0.026 \\
(0.016)\end{array}$ & $\begin{array}{c}-0.013 \\
(0.012)\end{array}$ & $\begin{array}{c}-0.024 \\
(0.018)\end{array}$ \\
\hline Thrid quartile & $\begin{array}{c}-0.002 \\
(0.012)\end{array}$ & $\begin{array}{l}0.030^{* *} \\
(0.014)\end{array}$ & $\begin{array}{c}-0.010 \\
(0.009)\end{array}$ & $\begin{array}{c}0.017 \\
(0.020)\end{array}$ & $\begin{array}{l}0.069^{* * *} \\
(0.019)\end{array}$ & $\begin{array}{l}0.052^{* * *} \\
(0.015)\end{array}$ & $\begin{array}{l}0.036^{* * *} \\
(0.011)\end{array}$ & $\begin{array}{l}0.039^{* *} \\
(0.016)\end{array}$ & $\begin{array}{l}0.025^{* *} \\
(0.011)\end{array}$ & $\begin{array}{c}0.025 \\
(0.017)\end{array}$ \\
\hline Fourth quartile & $\begin{array}{l}0.047^{* *} \\
(0.020)\end{array}$ & $\begin{array}{l}0.025^{* *} \\
(0.010)\end{array}$ & $\begin{array}{c}0.004 \\
(0.012)\end{array}$ & $\begin{array}{c}0.001 \\
(0.010)\end{array}$ & $\begin{array}{c}0.021 \\
(0.016)\end{array}$ & $\begin{array}{c}0.011 \\
(0.014)\end{array}$ & $\begin{array}{c}0.022^{*} \\
(0.013)\end{array}$ & $\begin{array}{c}0.022^{*} \\
(0.012)\end{array}$ & $\begin{array}{c}0.018^{*} \\
(0.010)\end{array}$ & $\begin{array}{c}0.015 \\
(0.013)\end{array}$ \\
\hline $\begin{array}{l}\text { Test equation coefficient } \\
(p \text {-value) }\end{array}$ & 0.1400 & 0.9420 & 0.2913 & 0.5037 & 0.1151 & 0.1072 & 0.5913 & 0.0148 & 0.0920 & 0.0933 \\
\hline
\end{tabular}

Sources: Penn World Tables version 6.2, Acemoglu et al. (2001), and authors' estimates.

Coefficients and robust standard errors clustered at country level (in parentheses) are obtained for each quartile by OLS estimates of an equation in which each country's growth rate of per capita GDP at time $t$ is regressed on one-year lag of each indicator of reforms per time and on one-year lag of the log of per capita GDP. All specifications include country and year fixed effects. The $p$-value of the test of equality of the coefficient estimates across quartiles is reported in the bottom row of the table. Annual data over 1973 to 2006 when available. GDP in real terms and PPP adjusted. Significant at $* 10 \%$, $* * 5 \%$, and $* * * 1 \%$.

Results are summarized in tables 3 and 4 for constraints on the executive and average risk of expropriation, respectively. The tables are organized in the same manner as in table 2 , reporting in each column different indicators of structural reform coefficients and their standard errors, estimated across different quartiles.

The main finding here is that a positive and statistically significant association between reforms and growth comes from the third and, partially, the second quartiles (table 3). Estimates for the first quartile show that only the two measures of international trade openness are associated with higher growth at a statistically significant level. Reforms for the domestic financial market and its banking subcomponent are positively associated with growth at a statistically significant level only in the second and third quartiles. In addition, their coefficient estimates are statistically different from each other across quartiles. Reforms of the securities markets display a statistically significant and positive coefficient in the second, third, and fourth quartiles, even though the coefficient estimates are not statistically different from each other across quartiles. Finally, current account and network reforms are associated at conventional statistical levels with higher growth for countries in the third quartile. Only for the network sector do the estimated coefficients differ from each other across quartiles. 22

With regard to the average risk of expropriation, estimates reported in table 4 show a positive and statistically significant association between reforms and growth coming mainly from the third quartile (specifically, for reforms of the current account, domestic financial sector, and its two subcomponents, external capital account, and subindex for residents) and the fourth one (in particular, for openness to international trade, securities market, external capital account and its subindex for resident). In the first quartile, only openness of the external capital account and its index for nonresident are positively associated with growth, at conventional statistical levels. Finally, it is worth noting that only reforms concerning the external capital accounts as captured by all three indices

\footnotetext{
22 We also performed the same exercise by grouping countries in different quartiles according to the quality of democratic institutions as measured by the variable polity 2 from the Polity IV project. The evidence of a significant and positive association between reforms and growth comes mainly from countries in the third quartile, even though coefficient estimates (with the exception for reforms in the banking sector) are not statistically different from each other across quartiles. To save space, we do not report these results, which are available on request from the authors.
} 
TABLE 5.-REFORMS AND GROWTH: ARELLANO-BOND GMM

\begin{tabular}{|c|c|c|c|c|c|c|c|c|c|c|}
\hline $\begin{array}{l}\text { Dependent Variable: } \\
\operatorname{lnGDP}(t)\end{array}$ & (1) & (2) & (3) & (4) & (5) & (6) & (7) & (8) & (9) & (10) \\
\hline \multicolumn{11}{|l|}{ Real sector reforms } \\
\hline Trade $(t-1)$ & $\begin{array}{c}0.031 \\
(0.020)\end{array}$ & & & & & & & & & \\
\hline Current account $(t-1)$ & & $\begin{array}{l}0.054^{* *} \\
(0.023)\end{array}$ & & & & & & & & \\
\hline Agriculture $(t-1)$ & & & $\begin{array}{l}0.055^{* *} \\
(0.022)\end{array}$ & & & & & & & \\
\hline Network $(t-1)$ & & & & $\begin{array}{c}0.001 \\
(0.029)\end{array}$ & & & & & & \\
\hline \multicolumn{11}{|l|}{ Financial sector reforms } \\
\hline Domestic finance $(t-1)$ & & & & & $\begin{array}{l}0.116^{* * *} \\
(0.025)\end{array}$ & & & & & \\
\hline Banking $(t-1)$ & & & & & & $\begin{array}{l}0.095^{* * *} \\
(0.022)\end{array}$ & & & & \\
\hline Securities $(t-1)$ & & & & & & & $\begin{array}{l}0.070^{* * *} \\
(0.016)\end{array}$ & & & \\
\hline Capital $(t-1)$ & & & & & & & & $\begin{array}{c}0.037 \\
(0.025)\end{array}$ & & \\
\hline Capital (resident) $(t-1)$ & & & & & & & & & $\begin{array}{r}0.034^{*} \\
(0.019)\end{array}$ & \\
\hline Capital (nonresident) $(t-1)$ & & & & & & & & & & $\begin{array}{c}0.024 \\
(0.023)\end{array}$ \\
\hline $\operatorname{lnGDP}(t-1)$ & $\begin{array}{l}0.913^{* * *} \\
(0.021)\end{array}$ & $\begin{array}{l}0.880^{* * *} \\
(0.023)\end{array}$ & $\begin{array}{l}0.941^{* * *} \\
(0.020)\end{array}$ & $\begin{array}{l}0.901^{* * *} \\
(0.022)\end{array}$ & $\begin{array}{l}0.954^{* * *} \\
(0.018)\end{array}$ & $\begin{array}{l}0.954^{* * *} \\
(0.018)\end{array}$ & $\begin{array}{l}0.935^{* * *} \\
(0.019)\end{array}$ & $\begin{array}{l}0.878^{* * *} \\
(0.023)\end{array}$ & $\begin{array}{l}0.884^{* * *} \\
(0.024)\end{array}$ & $\begin{array}{l}0.879^{* * *} \\
(0.023)\end{array}$ \\
\hline $\begin{array}{l}\text { Test second-order serial } \\
\text { correlation ( } p \text {-value })\end{array}$ & 0.180 & 0.205 & 0.438 & 0.186 & 0.796 & 0.816 & 0.752 & 0.216 & 0.210 & 0.210 \\
\hline Sargan test & 0.000 & 0.000 & 0.000 & 0.000 & 0.000 & 0.000 & 0.000 & 0.000 & 0.000 & 0.000 \\
\hline Observations & 3,264 & 3,411 & 3,267 & 3,665 & 2,562 & 2,562 & 2,562 & 3,411 & 3,436 & 3,411 \\
\hline
\end{tabular}

at hand have coefficient estimates that statistically differ from each other across quartiles.

\section{Robustness}

In this section we perform several econometric exercises to examine the robustness of the findings discussed in section IIIB. We first check whether our results hold when using the GMM estimator proposed by Arellano and Bond (1991). We then include a set of time-varying control variables and investigate whether our baseline estimates are heterogeneous across different time periods and income groups. We also estimate equation (1) by using lower-frequency data. Finally, we include in the baseline econometric model of section IIIB several indicators of structural reforms at the same time to check for a possible relevant source of omitted variable bias.

\section{A. Arellano-Bond GMM Estimation}

Through a simple manipulation, we can write equation (1) as

$$
\begin{aligned}
\ln G D P_{i, t}= & a_{0}+\bar{a}_{1} \ln G D P_{i, t-1}+a_{2} \text { Reform }_{i, t-1} \\
& +\eta_{i}+\delta_{t}+\varepsilon_{i t},
\end{aligned}
$$

where $\bar{a}_{1}=1+a_{1}$. Equation (1) is rearranged as a dynamic model in which the lagged dependent variable is included among the regressors (see Caselli, Esquivel, \& Lefort, 1996).
Fixed-effect OLS estimates are therefore inconsistent due to the correlation between the lagged dependent variable and the lagged error term. For fixed $N$, OLS estimates are consistent only for $T \rightarrow \infty$. Although the number of time periods in our data set is not too small, fixed-effect OLS estimates can still be inconsistent if the process for per capita income is persistent (see Wooldridge, 2002). To deal with this issue, we use the GMM estimator proposed by Arellano and Bond (1991), which takes the first differences of equation (2) in order to remove country-specific unobserved heterogeneity and uses two or more lags of the dependent variable as instruments.

Table 5 reports results from GMM estimation. By comparing these results with those in table 1, we note that the positive association between growth and openness to international trade as captured by the average tariff rates no longer holds, while the coefficient estimate of the variable measuring the lack of restrictions on current account transactions remains a positive and statistically significant. The estimates confirm the positive association between the liberalization of the agricultural market and growth, while the degree of liberalization in the network and electricity markets remains a statistically insignificant correlation with a country's economic performance.

Results for reforms in the financial sector are somewhat mixed compared to those reported in table 1. Specifically, the overall index of the domestic financial sector reform and its two subcomponents for banking and securities is associated with a higher rate of economic growth at a statistically 
TABLE 6.-BASELINE Growth REgRESSIONS With CONTROLS

\begin{tabular}{|c|c|c|c|c|c|c|c|c|c|c|}
\hline $\begin{array}{l}\text { Dependent Variable: } \\
\operatorname{lnGDP}(t)-\operatorname{lnGDP}(t-1)\end{array}$ & (1) & (2) & (3) & (4) & (5) & (6) & (7) & (8) & (9) & (10) \\
\hline \multicolumn{11}{|l|}{ Real sector reforms } \\
\hline Trade $(t-1)$ & $\begin{array}{r}0.021^{*} \\
(0.013)\end{array}$ & & & & & & & & & \\
\hline Current account $(t-1)$ & & $\begin{array}{l}0.034^{* * *} \\
(0.009)\end{array}$ & & & & & & & & \\
\hline Agriculture $(t-1)$ & & & $\begin{array}{l}0.024^{* * *} \\
(0.009)\end{array}$ & & & & & & & \\
\hline Network $(t-1)$ & & & & $\begin{array}{c}-0.009 \\
(0.012)\end{array}$ & & & & & & \\
\hline \multicolumn{11}{|l|}{ Financial sector reforms } \\
\hline Domestic finance $(t-1)$ & & & & & $\begin{array}{l}0.060^{* * *} \\
(0.015)\end{array}$ & & & & & \\
\hline Banking $(t-1)$ & & & & & & $\begin{array}{l}0.046^{* * *} \\
(0.014)\end{array}$ & & & & \\
\hline Securities $(t-1)$ & & & & & & & $\begin{array}{l}0.035^{* * *} \\
(0.009)\end{array}$ & & & \\
\hline Capital $(t-1)$ & & & & & & & & $\begin{array}{l}0.022^{* *} \\
(0.010)\end{array}$ & & \\
\hline Capital (resident) $(t-1)$ & & & & & & & & & $\begin{array}{l}0.017^{* *} \\
(0.007)\end{array}$ & \\
\hline Capital (nonresident) $(t-1)$ & & & & & & & & & & $\begin{array}{c}0.016 \\
(0.011)\end{array}$ \\
\hline $\operatorname{lnGDP}(t-1)$ & $\begin{array}{l}-0.057^{* * *} \\
(0.011)\end{array}$ & $\begin{array}{l}-0.053^{* * *} \\
(0.013)\end{array}$ & $\begin{array}{l}-0.048^{* * *} \\
(0.014)\end{array}$ & $\begin{array}{l}-0.058^{* * *} \\
(0.016)\end{array}$ & $\begin{array}{l}-0.060^{* * *} \\
(0.012)\end{array}$ & $\begin{array}{l}-0.059^{* * *} \\
(0.012)\end{array}$ & $\begin{array}{l}-0.067^{* * *} \\
(0.013)\end{array}$ & $\begin{array}{l}-0.054^{* * *} \\
(0.013)\end{array}$ & $\begin{array}{l}-0.053^{* * *} \\
(0.013)\end{array}$ & $\begin{array}{l}-0.053^{* * *} \\
(0.013)\end{array}$ \\
\hline Democracy $(t-1)$ & $\begin{aligned}-0.000 \\
(0.000)\end{aligned}$ & $\begin{array}{c}-0.001 \\
(0.000)\end{array}$ & $\begin{array}{c}-0.001 \\
(0.000)\end{array}$ & $\begin{array}{c}-0.001 \\
(0.000)\end{array}$ & $\begin{array}{l}-0.000 \\
(0.000)\end{array}$ & $\begin{array}{c}-0.000 \\
(0.000)\end{array}$ & $\begin{array}{c}-0.000 \\
(0.001)\end{array}$ & $\begin{array}{c}-0.001 \\
(0.000)\end{array}$ & $\begin{aligned}-0.000 \\
(0.000)\end{aligned}$ & $\begin{array}{c}-0.001 \\
(0.000)\end{array}$ \\
\hline Terms of trade $(t-1)$ & $\begin{array}{c}0.000 \\
(0.000)\end{array}$ & $\begin{array}{c}-0.000 \\
(0.000)\end{array}$ & $\begin{array}{c}-0.000 \\
(0.000)\end{array}$ & $\begin{array}{c}-0.000 \\
(0.000)\end{array}$ & $\begin{array}{c}0.000 \\
(0.000)\end{array}$ & $\begin{array}{c}0.000 \\
(0.000)\end{array}$ & $\begin{array}{r}-0.000 \\
(0.000)\end{array}$ & $\begin{array}{r}-0.000 \\
(0.000)\end{array}$ & $\begin{array}{c}-0.000 \\
(0.000)\end{array}$ & $\begin{array}{r}-0.000 \\
(0.000)\end{array}$ \\
\hline Tertiary enroll $(t-1)$ & $\begin{array}{r}0.033^{*} \\
(0.017)\end{array}$ & $\begin{array}{l}0.025 \\
(0.019)\end{array}$ & $\begin{array}{l}0.041^{*} \\
(0.023)\end{array}$ & $\begin{array}{c}0.034 \\
(0.023)\end{array}$ & $\begin{array}{c}0.026 \\
(0.018)\end{array}$ & $\begin{array}{c}0.027 \\
(0.018)\end{array}$ & $\begin{array}{c}0.028 \\
(0.019)\end{array}$ & $\begin{array}{c}0.017 \\
(0.020)\end{array}$ & $\begin{array}{c}0.022 \\
(0.020)\end{array}$ & $\begin{array}{c}0.018 \\
(0.020)\end{array}$ \\
\hline Observations & 2,460 & 2,580 & 2,402 & 2,584 & 2,114 & 2,114 & 2,114 & 2,580 & 2,583 & 2,580 \\
\hline$R^{2}$ & 0.180 & 0.164 & 0.189 & 0.172 & 0.184 & 0.180 & 0.183 & 0.161 & 0.159 & 0.160 \\
\hline
\end{tabular}

significant level. Among the indicators of capital account liberalization, only the one measuring the lack of restrictions imposed on residents maintains a statistically significant and positive coefficient estimate.

The $p$-values reported at the bottom of table 5 show that there is no statistically significant second-order serial correlation among the first-differenced error terms (an assumption required for the consistency of the estimates). Yet the Sargan test rejects, for all the specifications, the null hypothesis that the overidentifying assumptions are valid, which leads us to take these results with a word of caution.

\section{B. Additional Robustness Checks}

Next, we start assessing the robustness of our results to the inclusion in equation (1) of an additional set of time-varying control variables. Table 6 extends the results of table 1 by adding a one-year lag of three additional covariates: political institutions (as measured by the polity 2 indicator of quality of democracy from the Polity IV project), terms of trade, and tertiary educational attainment. Our results are broadly robust to the inclusion of this set of variables. In comparison to the results reported in table 1 , the index of liberalization of the capital account for nonresident is the only one to lose statistical significance. The sign of the coefficient estimate for the reforms in the electricity and telecommunication markets turns out to be negative but is still not statistically different from 0.23

We then investigate whether the empirical evidence about reforms and growth reported in table 1 is heterogeneous across different time periods. For instance, Billmeier and Nannicini (forthcoming), by using a different estimation method from ours, find evidence of a positive effect of economic liberalizations on growth, which weakens after 1989. We report estimates for the periods 1973 to 1989 and 1990 to 2006 in tables 7 and 8, respectively. Overall, the estimates for the years from 1973 to 1989 show a positive correlation between structural reforms and economic performance. It is worth noting that for the same period, the liberalization of the electricity and telecommunications markets displays a positive and statistically significant association with economic

\footnotetext{
${ }^{23}$ Results with alternative sets of control variables have not been reported to save space, but they are available on request from the authors. These controls include, among others, macropolicy variables (such as inflation), alternative measures of educational attainment (such as primary and secondary education), alternative measures of political institutions (from the Polity IV database), and alternative definitions of terms of trade.
} 
TABLE 7.-REFORMS AND GROWTH, 1973-1989

\begin{tabular}{|c|c|c|c|c|c|c|c|c|c|c|}
\hline $\begin{array}{l}\text { Dependent Variable: } \\
\text { lnGDP }(t)-\operatorname{lnGDP}(t-1)\end{array}$ & (1) & (2) & (3) & (4) & (5) & (6) & (7) & (8) & (9) & $(10)$ \\
\hline \multicolumn{11}{|l|}{ Real sector reforms } \\
\hline Trade $(t-1)$ & $\begin{array}{l}0.022^{* *} \\
(0.010)\end{array}$ & & & & & & & & & \\
\hline Current account $(t-1)$ & & $\begin{array}{l}0.051^{* * *} \\
(0.014)\end{array}$ & & & & & & & & \\
\hline Agriculture $(t-1)$ & & & $\begin{array}{c}0.002 \\
(0.012)\end{array}$ & & & & & & & \\
\hline Network $(t-1)$ & & & & $\begin{array}{l}0.102^{* * *} \\
(0.014)\end{array}$ & & & & & & \\
\hline \multicolumn{11}{|l|}{ Financial sector reforms } \\
\hline Domestic finance $(t-1)$ & & & & & $\begin{array}{l}0.053^{* *} \\
(0.021)\end{array}$ & & & & & \\
\hline Banking $(t-1)$ & & & & & & $\begin{array}{l}0.043^{* *} \\
(0.020)\end{array}$ & & & & \\
\hline Securities $(t-1)$ & & & & & & & $\begin{array}{l}0.032^{* * *} \\
(0.011)\end{array}$ & & & \\
\hline Capital $(t-1)$ & & & & & & & & $\begin{array}{l}0.054^{* * *} \\
(0.017)\end{array}$ & & \\
\hline Capital (resident) $(t-1)$ & & & & & & & & & $\begin{array}{l}0.038^{* * *} \\
(0.013)\end{array}$ & \\
\hline Capital (nonresident) $(t-1)$ & & & & & & & & & & $\begin{array}{l}0.037^{* *} \\
(0.014)\end{array}$ \\
\hline $\operatorname{lnGDP}(t-1)$ & $\begin{array}{l}-0.077^{* * *} \\
(0.018)\end{array}$ & $\begin{array}{l}-0.087^{* * *} \\
(0.019)\end{array}$ & $\begin{array}{l}-0.067^{* * *} \\
(0.016)\end{array}$ & $\begin{array}{l}-0.071^{* * *} \\
(0.013)\end{array}$ & $\begin{array}{l}-0.075^{* * *} \\
(0.018)\end{array}$ & $\begin{array}{l}-0.074^{* * *} \\
(0.018)\end{array}$ & $\begin{array}{l}-0.074^{* * *} \\
(0.020)\end{array}$ & $\begin{array}{l}-0.089^{* * *} \\
(0.019)\end{array}$ & $\begin{array}{l}-0.087^{* * *} \\
(0.019)\end{array}$ & $\begin{array}{l}-0.087^{* * *} \\
(0.019)\end{array}$ \\
\hline Observations & 1,313 & 1,599 & 1,452 & 1,695 & 1,160 & 1,160 & 1,160 & 1,599 & 1,599 & 1,599 \\
\hline$R^{2}$ & 0.240 & 0.200 & 0.172 & 0.181 & 0.237 & 0.235 & 0.235 & 0.200 & 0.199 & 0.198 \\
\hline
\end{tabular}

TABLE 8.-REFORMS AND GROWTH, 1990-2006

\begin{tabular}{|c|c|c|c|c|c|c|c|c|c|c|}
\hline $\begin{array}{l}\text { Dependent Variable: } \\
\operatorname{lnGDP}(t)-\operatorname{lnGDP}(t-1)\end{array}$ & (1) & (2) & (3) & (4) & $(5)$ & (6) & (7) & (8) & (9) & (10) \\
\hline \multicolumn{11}{|l|}{ Real sector reforms } \\
\hline Trade $(t-1)$ & $\begin{array}{c}0.018 \\
(0.020)\end{array}$ & & & & & & & & & \\
\hline Current account $(t-1)$ & & $\begin{array}{l}0.039^{* *} \\
(0.017)\end{array}$ & & & & & & & & \\
\hline Agriculture $(t-1)$ & & & $\begin{array}{l}0.047^{* *} \\
(0.019)\end{array}$ & & & & & & & \\
\hline Network $(t-1)$ & & & & $\begin{array}{c}0.000 \\
(0.014)\end{array}$ & & & & & & \\
\hline \multicolumn{11}{|l|}{ Financial sector reforms } \\
\hline Domestic finance $(t-1)$ & & & & & $\begin{array}{l}0.124^{* * *} \\
(0.026)\end{array}$ & & & & & \\
\hline Banking $(t-1)$ & & & & & & $\begin{array}{l}0.097^{* * *} \\
(0.024)\end{array}$ & & & & \\
\hline Securities $(t-1)$ & & & & & & & $\begin{array}{l}0.063^{* * *} \\
(0.012)\end{array}$ & & & \\
\hline Capital $(t-1)$ & & & & & & & & $\begin{array}{c}0.017 \\
(0.014)\end{array}$ & & \\
\hline Capital (resident) $(t-1)$ & & & & & & & & & $\begin{array}{c}0.018 \\
(0.011)\end{array}$ & \\
\hline Capital (nonresident) $(t-1)$ & & & & & & & & & & $\begin{array}{c}0.002 \\
(0.014)\end{array}$ \\
\hline $\operatorname{lnGDP}(t-1)$ & $\begin{array}{l}-0.124^{* * *} \\
(0.019)\end{array}$ & $\begin{array}{l}-0.188^{* * *} \\
(0.041)\end{array}$ & $\begin{array}{l}-0.118^{* * *} \\
(0.020)\end{array}$ & $\begin{array}{l}-0.129^{* * *} \\
(0.020)\end{array}$ & $\begin{array}{l}-0.116^{* * *} \\
(0.024)\end{array}$ & $\begin{array}{l}-0.113^{* * *} \\
(0.024)\end{array}$ & $\begin{array}{l}-0.120^{* * *} \\
(0.023)\end{array}$ & $\begin{array}{l}-0.186^{* * *} \\
(0.041)\end{array}$ & $\begin{array}{l}-0.178^{* * *} \\
(0.041)\end{array}$ & $\begin{array}{l}-0.186^{* * *} \\
(0.041)\end{array}$ \\
\hline Observations & 2,105 & 1,931 & 1,938 & 2,101 & 1,493 & 1,493 & 1,493 & 1,931 & 1,957 & 1,931 \\
\hline$R^{2}$ & 0.248 & 0.222 & 0.272 & 0.223 & 0.263 & 0.252 & 0.252 & 0.219 & 0.214 & 0.218 \\
\hline
\end{tabular}


TABLE 9.-REFORMS AND GROWTH, ADVANCED ECONOMIES

\begin{tabular}{|c|c|c|c|c|c|c|c|c|c|c|}
\hline $\begin{array}{l}\text { Dependent Variable: } \\
\text { lnGDP }(t)-\operatorname{lnGDP}(t-1)\end{array}$ & (1) & (2) & (3) & (4) & (5) & (6) & (7) & (8) & (9) & (10) \\
\hline \multicolumn{11}{|l|}{ Real sector reforms } \\
\hline Trade $(t-1)$ & $\begin{array}{c}0.016 \\
(0.015)\end{array}$ & & & & & & & & & \\
\hline Current account $(t-1)$ & & $\begin{array}{l}0.025^{* *} \\
(0.011)\end{array}$ & & & & & & & & \\
\hline Agriculture $(t-1)$ & & & $\begin{array}{c}0.033 \\
(0.024)\end{array}$ & & & & & & & \\
\hline Network $(t-1)$ & & & & $\begin{array}{c}0.002 \\
(0.006)\end{array}$ & & & & & & \\
\hline \multicolumn{11}{|l|}{ Financial sector reforms } \\
\hline Domestic finance $(t-1)$ & & & & & $\begin{array}{c}0.020 \\
(0.018)\end{array}$ & & & & & \\
\hline Banking $(t-1)$ & & & & & & $\begin{array}{c}0.010 \\
(0.013)\end{array}$ & & & & \\
\hline Securities $(t-1)$ & & & & & & & $\begin{array}{r}0.023^{*} \\
(0.012)\end{array}$ & & & \\
\hline Capital $(t-1)$ & & & & & & & & $\begin{array}{c}0.017 \\
(0.011)\end{array}$ & & \\
\hline Capital (resident) $(t-1)$ & & & & & & & & & $\begin{array}{c}0.011 \\
(0.010)\end{array}$ & \\
\hline Capital (nonresident) $(t-1)$ & & & & & & & & & & $\begin{array}{l}0.016 \\
(0.011)\end{array}$ \\
\hline $\operatorname{lnGDP}(t-1)$ & $\begin{array}{l}-0.045^{* * *} \\
(0.011)\end{array}$ & $\begin{array}{l}-0.052^{* * *} \\
(0.017)\end{array}$ & $\begin{array}{l}-0.023^{* * *} \\
(0.007)\end{array}$ & $\begin{array}{l}-0.035^{* * *} \\
(0.008)\end{array}$ & $\begin{array}{l}-0.036^{* * *} \\
(0.008)\end{array}$ & $\begin{array}{l}-0.036^{* * *} \\
(0.009)\end{array}$ & $\begin{array}{l}-0.036^{* * *} \\
(0.008)\end{array}$ & $\begin{array}{l}-0.053^{* * *} \\
(0.017)\end{array}$ & $\begin{array}{l}-0.053^{* * *} \\
(0.017)\end{array}$ & $\begin{array}{l}-0.054^{* * *} \\
(0.017)\end{array}$ \\
\hline Observations & 983 & 966 & 745 & 898 & 886 & 886 & 886 & 966 & 966 & 966 \\
\hline$R^{2}$ & 0.326 & 0.333 & 0.402 & 0.358 & 0.351 & 0.348 & 0.362 & 0.329 & 0.328 & 0.329 \\
\hline
\end{tabular}

growth, while compared with table 1 , such a correlation no longer holds for the agricultural market reforms. ${ }^{24}$

Estimates for the years from 1990 to 2006 (table 8) confirm the positive association between growth and all three available indices of domestic financial sector reforms, which we detect in both table 1 and for the period 1973 to 1989. The evidence about openness to international trade is mixed: only the variable that captures the (lack of) restrictions on current account transactions maintains a positive and statistically significant coefficient. When we focus on the period 1990 to 2006, reforms of the agricultural markets display, as in table 1 , a positive and statistically significant association with economic growth. There is no significant association between growth and reforms in the network industries (as in table 1), and openness of the external capital account does not display a significant correlation with economic growthdifferent from the period 1973 to 1989 and the estimates in table 1.25

We also analyze whether the association between reforms and economic growth is heterogeneous across different income groups. We code the countries in our sample as

\footnotetext{
24 We take the results about the network sector with a word of caution For the period 1973 to 1989 , this variable has a value of 0 until the 75 th percentile of the distribution. Results seem to be driven by a few countries that started opening up this sector in the period under consideration.

25 Figure 1 suggests that reforms of the network sector started around 1990 , with a sharp increase in the past twenty years. Panel regressions do not show any significant correlation between reforms of the network sector and growth, probably because the inclusion of year fixed effects captures a trend common to all countries in the process of reforming this sector.
}

advanced or emerging and developing economies, according to the World Economic Outlook Database classification (see appendix 1). ${ }^{26}$ Table 9 reports results for advanced economies, while table 10 for emerging and developing economies. As it concerns advanced economies, the indicators that display a statistically significant and positive coefficient are openness to international trade (as captured by the lack of restrictions on the current account) and the reforms of the securities markets. These findings are broadly consistent with those concerning countries in the fourth quartile of distance to the technological frontier (see table 2), for which we find that reforms of the current account and the securities sector have positive and statistically significant coefficient estimates, which are also statistically different from those of the other quartiles. By comparing estimates for emerging and developing economies with those reported in table 1 , we note that the three available indicators of reforms of the capital account no longer show a statistically significant association with economic growth. As in table 1, reforms of the network sector (electricity and telecommunications) display a positive but not statistically significant coefficient estimate.

Johnson et al. (2009) warn about the implications from estimating growth regressions with annual PPP-corrected GDP data from the Penn World Tables due to the presence of measurement error. We take this warning seriously, and although we believe that for the question at hand using reform data at an annual frequency is conceptually the preferred

\footnotetext{
${ }^{26}$ Available at: http://www.imf.org/external/pubs/ft/weo/2011/02/weodata /weoselagr.aspx.
} 
TABle 10.-Reforms AND Growth, EMERging AND Developing ECONOMIES

\begin{tabular}{|c|c|c|c|c|c|c|c|c|c|c|}
\hline $\begin{array}{l}\text { Dependent Variable: } \\
\operatorname{lnGDP}(t)-\operatorname{lnGDP}(t-1)\end{array}$ & (1) & (2) & (3) & (4) & $(5)$ & (6) & (7) & (8) & (9) & (10) \\
\hline \multicolumn{11}{|l|}{ Real sector reforms } \\
\hline Trade $(t-1)$ & $\begin{array}{c}0.021^{*} \\
(0.012)\end{array}$ & & & & & & & & & \\
\hline Current account $(t-1)$ & & $\begin{array}{l}0.031^{* * *} \\
(0.010)\end{array}$ & & & & & & & & \\
\hline Agriculture $(t-1)$ & & & $\begin{array}{r}0.015^{*} \\
(0.009)\end{array}$ & & & & & & & \\
\hline Network $(t-1)$ & & & & $\begin{array}{c}0.010 \\
(0.013)\end{array}$ & & & & & & \\
\hline \multicolumn{11}{|l|}{ Financial sector reforms } \\
\hline Domestic finance $(t-1)$ & & & & & $\begin{array}{l}0.075^{* * *} \\
(0.020)\end{array}$ & & & & & \\
\hline Banking $(t-1)$ & & & & & & $\begin{array}{l}0.058^{* * *} \\
(0.018)\end{array}$ & & & & \\
\hline Securities $(t-1)$ & & & & & & & $\begin{array}{l}0.040^{* * *} \\
(0.011)\end{array}$ & & & \\
\hline Capital $(t-1)$ & & & & & & & & $\begin{array}{c}0.016 \\
(0.010)\end{array}$ & & \\
\hline Capital (resident) $(t-1)$ & & & & & & & & & $\begin{array}{c}0.012 \\
(0.008)\end{array}$ & \\
\hline Capital (nonresident) $(t-1)$ & & & & & & & & & & $\begin{array}{c}0.010 \\
(0.009)\end{array}$ \\
\hline $\operatorname{lnGDP}(t-1)$ & $\begin{array}{l}-0.053^{* * *} \\
(0.009)\end{array}$ & $\begin{array}{c}-0.055^{* * *} \\
(0.013)\end{array}$ & $\begin{array}{l}-0.040^{* * *} \\
(0.009)\end{array}$ & $\begin{array}{c}-0.048^{* * *} \\
(0.010)\end{array}$ & $\begin{array}{c}-0.048^{* * *} \\
(0.010)\end{array}$ & $\begin{array}{c}-0.047^{* * *} \\
(0.010)\end{array}$ & $\begin{array}{c}-0.056^{* * *} \\
(0.010)\end{array}$ & $\begin{array}{c}-0.054^{* * *} \\
(0.012)\end{array}$ & $\begin{array}{c}-0.052^{* * *} \\
(0.012)\end{array}$ & $\begin{array}{l}-0.054^{* * *} \\
(0.012)\end{array}$ \\
\hline Observations & 2,432 & 2,564 & 2,645 & 2,898 & 1,767 & 1,767 & 1,767 & 2,564 & 2,590 & 2,564 \\
\hline$R^{2}$ & 0.190 & 0.135 & 0.163 & 0.143 & 0.193 & 0.189 & 0.188 & 0.132 & 0.131 & 0.132 \\
\hline
\end{tabular}

choice, we have reestimated our baseline results by using three- and five-year interval data. As shown in table 11, which reports estimates from using three-year interval data, our main results are broadly robust: among the reforms that display a positive and statistically significant coefficient estimate in table 1 , only the index for the liberalization of the agricultural sector is no longer statistically significant. 27

When estimating specification (1) in section IIIB, we include one indicator of structural reform at a time. A concern with these results is that the process of reforming might involve several sectors of the economy at the same time. If this is the case, our indicators of structural reforms are likely to be correlated with each other.

Estimates reported in table 12 deal with this issue. The table is organized in the following manner. Openness to international trade is measured by the average tariff rates in columns 1 to 4 , and by the restrictions on current account transactions in columns 5 to 8 . In columns 1 and 5, we consider the broader indices of liberalization of the domestic and international financial sectors, together with the indicators for the agricultural, electricity, and telecommunication markets, which are included in all columns, 1 to 8 . We include the two subindices of reform for the banking and securities sectors rather than the

\footnotetext{
27 When we estimate equation (1) by using five-year interval data, the following indices display a positive and statistical significant association with economic growth: liberalization of the current account, the overall domestic financial sector and its banking component, openness of the external capital account, and its subcomponent for resident. To save space, we do not report these results, which are available on request from the authors.
}

overall indicator for the domestic financial market in columns 2 and 6 . We consider the openness of the capital account for resident and nonresident rather than the general index of liberalization of the external capital account in columns 3 and 7. Finally, in columns 4 and 8 , we include at the same time the two subindices of reforms for the domestic financial sectors (banking and securities) and the international capital account (resident and nonresident).

By comparing these results with those reported in table 1 , the indicators of openness to international trade (as measured by both average tariff rates and by the restrictions on the current account), as well as the general index and the two subindices of openness of the external capital account, never display a statistically significant association with economic growth. The coefficient estimate for the network industries remains statistically not different from 0 . Reforms in the agricultural market and the overall domestic financial sector instead maintain a positive and statistically significant association with economic growth. As it concerns specifically the domestic financial sector, the securities market reform displays a statistically significant and positive association with economic growth in all the specifications in which it is included (columns 2, 4, 6, and 8), while the positive coefficient estimate for the liberalization of the banking sector is statistically significant at conventional levels only when we measure openness to international trade with the restrictions imposed on the current account (columns 6 and 8).

To summarize, the results from the baseline growth regressions reported in table 1 are broadly robust to GMM 
TABLE 11.-REFORMS AND GROWTH, THREE-YeAR INTERVAL DATA

\begin{tabular}{|c|c|c|c|c|c|c|c|c|c|c|}
\hline $\begin{array}{l}\text { Dependent Variable: } \\
\text { lnGDP }(t)-\operatorname{lnGDP}(t-1)\end{array}$ & (1) & (2) & (3) & (4) & (5) & (6) & (7) & (8) & (9) & $(10)$ \\
\hline \multicolumn{11}{|l|}{ Real sector reforms } \\
\hline Trade $(t-3)$ & $\begin{array}{l}0.063^{* *} \\
(0.032)\end{array}$ & & & & & & & & & \\
\hline Current account $(t-3)$ & & $\begin{array}{l}0.090^{* * *} \\
(0.027)\end{array}$ & & & & & & & & \\
\hline Agriculture $(t-3)$ & & & $\begin{array}{c}0.020 \\
(0.022)\end{array}$ & & & & & & & \\
\hline Network $(t-3)$ & & & & $\begin{array}{c}0.007 \\
(0.024)\end{array}$ & & & & & & \\
\hline \multicolumn{11}{|l|}{ Financial sector reforms } \\
\hline Domestic finance $(t-3)$ & & & & & $\begin{array}{l}0.108^{* * *} \\
(0.038)\end{array}$ & & & & & \\
\hline Banking $(t-3)$ & & & & & & $\begin{array}{l}0.081^{* *} \\
(0.034)\end{array}$ & & & & \\
\hline Securities $(t-3)$ & & & & & & & $\begin{array}{l}0.070^{* * *} \\
(0.021)\end{array}$ & & & \\
\hline Capital $(t-3)$ & & & & & & & & $\begin{array}{l}0.056^{* *} \\
(0.026)\end{array}$ & & \\
\hline Capital (resident) $(t-3)$ & & & & & & & & & $\begin{array}{c}0.040^{*} \\
(0.022)\end{array}$ & \\
\hline Capital (nonresident) $(t-3)$ & & & & & & & & & & $\begin{array}{r}0.041^{*} \\
(0.024)\end{array}$ \\
\hline $\operatorname{lnGDP}(t-3)$ & $\begin{array}{c}-0.160^{* * *} \\
(0.023)\end{array}$ & $\begin{array}{c}-0.173^{* * *} \\
(0.031)\end{array}$ & $\begin{array}{c}-0.129^{* * *} \\
(0.025)\end{array}$ & $\begin{array}{l}-0.145^{* * *} \\
(0.025)\end{array}$ & $\begin{array}{l}-0.131^{* * *} \\
(0.022)\end{array}$ & $\begin{array}{l}-0.130^{* * *} \\
(0.022)\end{array}$ & $\begin{array}{l}-0.139^{* * *} \\
(0.022)\end{array}$ & $\begin{array}{l}-0.172^{* * *} \\
(0.030)\end{array}$ & $\begin{array}{l}-0.169^{* * *} \\
(0.030)\end{array}$ & $\begin{array}{l}-0.172^{* * *} \\
(0.030)\end{array}$ \\
\hline Observations & 1,110 & 1,166 & 1,119 & 1,259 & 878 & 878 & 878 & 1,166 & 1,174 & 1,166 \\
\hline$R^{2}$ & 0.416 & 0.307 & 0.333 & 0.316 & 0.399 & 0.395 & 0.400 & 0.301 & 0.299 & 0.300 \\
\hline
\end{tabular}

TABLE 12.-GROWTH REgRESSIONS, All INDICES OF REFORMS

\begin{tabular}{|c|c|c|c|c|c|c|c|c|}
\hline $\begin{array}{l}\text { Dependent Variable: } \\
\text { lnGDP }(t)-\operatorname{lnGDP}(t-1)\end{array}$ & (1) & (2) & (3) & (4) & (5) & (6) & (7) & (8) \\
\hline \multicolumn{9}{|l|}{ Real sector reforms } \\
\hline Trade $(t-1)$ & $\begin{array}{c}0.012 \\
(0.011)\end{array}$ & $\begin{array}{c}0.011 \\
(0.011)\end{array}$ & $\begin{array}{c}0.012 \\
(0.011)\end{array}$ & $\begin{array}{c}0.010 \\
(0.011)\end{array}$ & & & & \\
\hline Current account $(t-1)$ & & & & & $\begin{array}{c}0.017 \\
(0.015)\end{array}$ & $\begin{array}{c}0.017 \\
(0.015)\end{array}$ & $\begin{array}{c}0.016 \\
(0.015)\end{array}$ & $\begin{array}{c}0.017 \\
(0.015)\end{array}$ \\
\hline Agriculture $(t-1)$ & $\begin{array}{r}0.018^{*} \\
(0.010)\end{array}$ & $\begin{array}{r}0.018^{*} \\
(0.010)\end{array}$ & $\begin{array}{r}0.018^{*} \\
(0.010)\end{array}$ & $\begin{array}{r}0.018^{*} \\
(0.010)\end{array}$ & $\begin{array}{l}0.022^{* *} \\
(0.010)\end{array}$ & $\begin{array}{l}0.021^{* *} \\
(0.010)\end{array}$ & $\begin{array}{l}0.021^{* *} \\
(0.010)\end{array}$ & $\begin{array}{l}0.021^{* *} \\
(0.010)\end{array}$ \\
\hline Network $(t-1)$ & $\begin{array}{r}-0.002 \\
(0.010)\end{array}$ & $\begin{array}{r}-0.002 \\
(0.009)\end{array}$ & $\begin{array}{r}-0.003 \\
(0.010)\end{array}$ & $\begin{array}{r}-0.002 \\
(0.010)\end{array}$ & $\begin{array}{c}-0.005 \\
(0.011)\end{array}$ & $\begin{array}{c}-0.005 \\
(0.011)\end{array}$ & $\begin{array}{c}-0.006 \\
(0.011)\end{array}$ & $\begin{array}{c}-0.005 \\
(0.011)\end{array}$ \\
\hline \multicolumn{9}{|l|}{ Financial sector reforms } \\
\hline Domestic finance $(t-1)$ & $\begin{array}{l}0.037^{* * *} \\
(0.014)\end{array}$ & & $\begin{array}{l}0.037^{* * *} \\
(0.014)\end{array}$ & & $\begin{array}{l}0.049^{* * *} \\
(0.015)\end{array}$ & & $\begin{array}{l}0.049^{* * *} \\
(0.016)\end{array}$ & \\
\hline Banking $(t-1)$ & & $\begin{array}{l}0.015 \\
(0.013)\end{array}$ & & $\begin{array}{c}0.015 \\
(0.013)\end{array}$ & & $\begin{array}{r}0.026^{*} \\
(0.014)\end{array}$ & & $\begin{array}{r}0.026^{*} \\
(0.015)\end{array}$ \\
\hline Securities $(t-1)$ & & $\begin{array}{l}0.029^{* * *} \\
(0.009)\end{array}$ & & $\begin{array}{l}0.029^{* * *} \\
(0.009)\end{array}$ & & $\begin{array}{l}0.029^{* * *} \\
(0.009)\end{array}$ & & $\begin{array}{l}0.030^{* * *} \\
(0.009)\end{array}$ \\
\hline Capital $(t-1)$ & $\begin{array}{c}0.002 \\
(0.010)\end{array}$ & $\begin{array}{c}0.000 \\
(0.010)\end{array}$ & & & $\begin{array}{r}-0.012 \\
(0.013)\end{array}$ & $\begin{array}{c}-0.014 \\
(0.014)\end{array}$ & & \\
\hline Capital (resident) $(t-1)$ & & & $\begin{array}{c}0.007 \\
(0.008)\end{array}$ & $\begin{array}{c}0.006 \\
(0.008)\end{array}$ & & & $\begin{array}{r}-0.002 \\
(0.011)\end{array}$ & $\begin{array}{r}-0.002 \\
(0.011)\end{array}$ \\
\hline Capital (nonresident) $(t-1)$ & & & $\begin{array}{c}-0.006 \\
(0.010)\end{array}$ & $\begin{array}{c}-0.008 \\
(0.010)\end{array}$ & & & $\begin{array}{c}-0.011 \\
(0.011)\end{array}$ & $\begin{array}{c}-0.012 \\
(0.011)\end{array}$ \\
\hline $\operatorname{lnGDP}(t-1)$ & $\begin{array}{l}-0.036^{* * *} \\
(0.007)\end{array}$ & $\begin{array}{l}-0.039^{* * *} \\
(0.008)\end{array}$ & $\begin{array}{l}-0.037^{* * *} \\
(0.007)\end{array}$ & $\begin{array}{l}-0.040^{* * *} \\
(0.008)\end{array}$ & $\begin{array}{l}-0.039^{* * *} \\
(0.008)\end{array}$ & $\begin{array}{l}-0.042^{* * *} \\
(0.008)\end{array}$ & $\begin{array}{l}-0.039^{* * *} \\
(0.008)\end{array}$ & $\begin{array}{c}-0.043^{* * *} \\
(0.008)\end{array}$ \\
\hline Observations & 2,137 & 2,137 & 2,137 & 2,137 & 2,235 & 2,235 & 2,235 & 2,235 \\
\hline$R^{2}$ & 0.222 & 0.227 & 0.223 & 0.228 & 0.212 & 0.216 & 0.212 & 0.216 \\
\hline
\end{tabular}

Sources: Penn World Tables version 6.2 and authors' estimates.

Robust standard errors clustered at country level in parentheses. All specifications are estimated by OLS and include country and year fixed effects. Annual data over 1973-2006 when available. GDP in real terms and PPP adjusted. Significant at $* 10 \%, * * 5 \%$, and $* * * 1 \%$. 
estimation, to the inclusion of control variables, and to the use of lower-frequency data. While for the period 1973 to 1989 , our estimates show a positive association between reforms and growth for all our indicators of reforms with the exception of the agricultural market, the evidence is mixed for the years after 1989. The association between reforms and growth holds for a fairly large number of economic sectors in the case of emerging and developing economies, while it is limited to only the openness to international trade (as measured by the lack of restrictions on the current account) and the securities sector in the case of advanced economies. Finally, when considering more than one index of reforms at the same time, reforms in the agricultural market, the overall domestic financial market, and the finicial market's securities subcomponent display a positive and statistically significant association with a country's economic performance.

\section{Conclusion}

This paper examines whether real and financial reforms over the past three decades have been associated with higher growth and whether there has been a differential growth response due to a country's institutional environment. Underpinning the empirical analysis is a significant data collection effort that involves the compilation of indicators of structural reforms for a large sample of developing and developed countries over the past three decades. Not only is the resulting data set unique in its country and time coverage, but it is also much broader in terms of the sectoral coverage of reformsas long as it includes indicators of liberalization in domestic product markets, international trade, several indicators of liberalization of the domestic financial sector, and measures of the capital account liberalization.

Our main findings are as follows. First, illustrative growth breaks analysis reveals a broadly positive (average) association between real and financial reforms and growth. The first two exercises (plotting the level of reform indices around growth breaks and reporting growth conditional on observing liberalization upticks) show that while there is a positive association between real and financial reforms and growth breaks, reverse causation is also at play. The third exercise reveals that focusing only on average reform performances may be masking botched reforms that resulted in growth disasters. The final exercise shows some evidence in favor of the hypothesis that crises may lead to the adoption of subsequent structural reforms.

Second, panel growth regression analysis provides evidence of a broad positive association between both real and financial sector reforms and growth. However, as in the growth breaks analysis, also in this case the average positive reform-growth relationship masks considerable heterogeneity related to a country's constraints on the authority of the executive power and its distance to the technology frontier. Regarding the distance to the technological frontier, there is no evidence of a positive relationship for countries far away from the technology frontier. This may be because markets or institutions in such economies are still not sufficiently developed to allow taking full advantage of substantial structural reforms. Reforms of the current account and the securities markets have a positive and statistically significant association with growth for countries close to the technology frontier, which may indicate that openness to international competition and the availability of financial instruments may favor innovation. Perhaps one of the most interesting results is the fact that reforms of the overall domestic financial sector and of its banking subcomponent exhibit positive association with growth for countries in the middle two quartiles (neither too far from nor too close to the technology frontier). This result may suggest that domestic financial reforms can facilitate the financing of technology adoption in dynamic developing economies and contribute, in this manner, to higher productivity and economic growth. The main finding, concerning constraints on the executive power is the significant positive correlation between reforms of the overall domestic financial and banking sectors and growth for countries with intermediate levels of constraints on the executive authority. This is quite an intriguing finding, as it is consistent with the result concerning the distance to the technology frontier. Taken together, these heterogeneity results suggest that reforms are more effective when markets and institutions are not at their infancy but at a somewhat more advanced stage in their process of development.

We caution that our results should be taken as evidence of strong associations rather than causation. While it is certainly the case that reforms are at least partially determined by the political process, appropriate instrumental variables that could resolve this and other sources of endogeneity are particularly difficult to find. Having said that, we do not view this as a drawback of this paper but rather a constraint inherently embedded in the complex composition of structural reforms. The heterogeneous effects that key variables-like the broad institutional environment or the distance from the technological frontier-have on the reform-growth relationship are remarkable, and we hope that together with the novel data set on reforms, this will stimulate further research on this important issue. In addition, while regression results reporting average effects are valuable exercises to obtain broad associations, they cannot tell the whole story. As shown in the last two exercises on growth breaks analysis in section IIIA, there is substantial variation in reform outcomes (including reform attempts associated with severe growth decelerations). Therefore, regression results should be complemented with more thorough and detailed event analysis. Such direction is both intriguing and potentially fruitful.

\section{REFERENCES}

Abiad, Abdul, Enrica Detragiache, and Thierry Tressel, "A New Database of Financial Reforms," IMF Staff Papers 57:2 (2008), 281-302.

Acemoglu, Daron, Philippe Aghion, and Fabrizio Zilibotti, "Distance to Frontier, Selection, and Economic Growth," Journal of the European Economic Association 4:1 (2006), 37-74.

Acemoglu, Daron, Simon Johnson, Pablo Querubin, and James A. Robinson, "When Does Policy Reform Work? The Case of Central Bank 
Independence," Brookings Papers on Economic Activity 39:1 (2008), 351-429.

Acemoglu, Daron, Simon Johnson, and James A. Robinson, "The Colonial Origins of Comparative Development: An Empirical Investigaion," American Economic Review 91 (2001), 1369-1401.

Aghion, Philippe, Philippe Askenazy, Renaud Bourles, Gilbert Cette, and Nicolas Dromel, "Education, Market Rigidities and Growth," Economics Letters 102 (2009), 62-65.

Aghion, Philippe, Leah Boustan, Caroline Hoxby, and Jerome Vandenbussche, "Exploiting States' Mistake to Evaluate the Causal Impact of Higher Education on Growth," Unpublished manuscript, Harvard University (2005).

Aghion, Philippe, and Peter Howitt, "A Model of Growth through Creative Destruction,” Econometrica 60 (1992), 323-351.

"Growth with Quality-Improving Innovations: An Integrated Framework," (1:67-110), in Philippe Aghion and Steven N. Durlauf (eds.), Handbook of Economic Growth (Amsterdam: Elsevier Science, 2005).

_ "Appropriate Growth Policy: A Unifying Framework," Journal of the European Economic Association 4 (2006), 269-314.

Aghion, Philippe, Peter Howitt, and David Mayer-Foulkes, "The Effect of Financial Development on Convergence: Theory and Evidence," Quarterly Journal of Economics 120:1 (2005), 173-222.

Anderson, Kim, Will Martin, and Dominique van der Mensbrugghe, "Impact of Global Trade and Subsidy Policies on Developing Country Trade," Journal of World Trade 40 (2006), 945968.

Antoshin, Sergei, Andrew Berg, and Marcos Souto, "Testing for Structural Breaks in Small Samples," IMF working papers 08/75 (2008).

Arellano, Manuel, and Stephen R. Bond, "Some Tests of Specification for Panel Data: Monte Carlo Evidence and an Application to Employment Equations," Review of Economic Studies 58 (1991), 277-297.

Bai, Jushan, and Pierre Perron, "Estimating and Testing Linear Models with Multiple Structural Changes," Econometrica 66:1 (1998), 47-78.

Bekaert, Geert, Campbell R. Harvey, and Christian Lundblad, "Does Financial Liberalization Spur Growth?” Journal of Financial Economics 77:1 (2005), 3-55.

Ben-David, Dan, and David H. Papell, "Slowdowns and Meltdowns: Postwar Growth Evidence from 74 Countries," this REVIEW 80 (1998), 561-571.

Berg, Andrew, and Anne O. Krueger, "Trade, Growth, and Poverty: A Selective Survey," IMF working paper 03/30 (2003).

Berg, Andy, Jonathan D. Ostry, and Jeromin Zettelmeyer, "What Makes Growth Sustained," Journal of Development Economics 98 (2012), 149-166.

Billmeier, Andreas, and Tommaso Nannicini, "Assessing Economic Liberalization Episodes: A Synthetic Control Approach," this REVIEW (forthcoming).

Caselli, Francesco, Gerardo Esquivel, and Fernando Lefort, "Reopening the Convergence Debate: A New Look at Cross-Country Growth Empirics," Journal of Economic Growth 1 (1996), 363-389.

Dollar, David, and Aart Kraay, "Trade, Growth, and Poverty," Economic Journal 114 (2004), 22-49.

Drazen, Allan, Political Economy in Macroeconomics (Princeton, NJ: Princeton University Press, 2000).

Drazen, Allan, and William Easterly, "Do Crises Induce Reform? Simple Empirical Tests of Conventional Wisdom," Economics and Politics 13 (2001), 129-157.

Easterly, William, "National Policies and Economic Growth: A Reappraisal," (1:1015-1059), in Philippe Aghion and Steven N. Durlauf (eds.), Handbook of Economic Growth (Amsterdam: Elsevier Science, 2005).

Easterly, William, and Ross Levine, "Tropics, Germs, and Crops: How Endowments Influence Economic Development," Journal of Monetary Economics 50:1 (2003), 3-39.

Frankel, Jeffrey A., and David Romer, "Does Trade Cause Growth?" American Economic Review 89 (1999), 379-399.

Hausmann, Ricardo, Lant Prichett, and Dani Rodrik, "Growth Accelerations," Journal of Economic Growth 10 (2005), 303-329.

Johnson, Simon, William Larson, Chris Papageorgiou, and Arvind Subramanian, "Is Newer Better? Penn World Table Revisions and Their Impact on Growth Estimates," NBER working paper 15455 (2009).

Jones, Benjamin F., and Benjamin A. Olken, "The Anatomy of Start-Stop Growth," this REVIEW 90 (2008), 582-587.

Levine, Ross, "Financial Development and Economic Growth: Views and Agenda," Journal of Economic Literature 35 (1997), 688-726.

- "Finance and Growth: Theory and Evidence" (1:865-934), in Philippe Aghion and Stevenen N. Durlauf (eds.), Handbook of Economic Growth (Amsterdam: Elsevier Science, 2005).

Marshall, Monty G., Ted Robert Gurr, and Keith Jaggers, Polity IV Project, Political Regime Characteristics and Transitions, 1800 2009 (Vienna, VA: Center for Systemic Peace, 2010).

Nelson, Richard, and Edmund Phelps, "Investment in Humans, Technological Diffusion, and Economic Growth," American Economic Review, Papers and Proceedings 61:1-2 (1966), 69-75.

Nicoletti, Giuseppe, and Stefano Scarpetta, "Regulation, Productivity and Growth. OECD Evidence,” Economic Policy 18:36 (2003), 9-72.

Pritchett, Lant, "Understanding Patterns of Economic Growth: Searching for Hills among Plateaus, Mountains, and Plains," World Bank Economic Review 14 (2000), 221-225.

Quinn, Dennis P., and A. Maria Toyoda, "Does Capital Account Liberalization Lead to Growth?" Review of Financial Studies 21 (2008), 1403-1449.

Rodriguez, Francisco, and Dani Rodrik, "Trade Policy and Economic Growth: A Skeptic's Guide to the Cross-National Evidence" in Ben Bernanke and Kenneth Rogoff (eds.), Macroeconomics Annual 2000 (Cambridge: MIT Press, 2000).

Rodrik, Dani, "Growth Strategies" (1:967-1014), in Philippe Aghion and Steven N. Durlauf (eds.), Handbook of Economic Growth (Amsterdam: Elsevier Science, 2005).

Rodrik, Dani, Arvind Subramanian, and Francesco Trebbi, "Institutions Rule: The Primacy of Institutions over Geography and Integration in Economic Development," Journal of Economic Growth 9 (2004), 131-165.

Sachs, Jeffrey D., and Andrew Warner, "Economic Reform, and the Process of Global Integration," Brookings Papers on Economic Activity 26 (1995), 1-118.

Schumpeter, Joseph, "The Instability of Capitalism," Economic Journal 38 (1928), 361-386.

Capitalism, Socialism and Democracy (New York: Harper and Brothers, 1942).

Tokarick, Stephen, "Dispelling Some Misconceptions about Agricultural Trade Liberalization," Journal of Economic Perspectives 22 (2008), 199-216.

Williamson, John, "What Should the World Bank Think about the Washington Consensus?" World Bank Research Observer 15 (2000), 251-264.

Wooldridge, Jeffrey M., Econometric Analysis of Cross-Section and Panel Data (Cambridge, MA: MIT Press, 2002).

Vandenbussche, Jerome, Philippe Aghion, and Costas Meghir, "Growth, Distance to Frontier and Composition of Human Capital," Journal of Economic Growth 11 (2006), 97-127. 